\title{
Dijitalleşen Kentlerde Yönetişim: Marmara Bölgesi Büyükşehir Belediyeleri'nin Karşılaştırmalı E-Belediyecilik Uygulamaları
}

\author{
Prof. Dr. İdil Sayımer ${ }^{1 *}$ \\ Arş. Gör. Zeynep Benan Dondurucu ${ }^{2}$ \\ Dr. Öğr. Üyesi Banu Küçüksaraç 3
}

Geliş tarihi: 25.09 .2019

Kabul tarihi: 10.11 .2019

\section{Atıf bilgisi:}

IBAD Sosyal Bilimler Dergisi

Sayı: 5 Sayfa: $420-443$

Yıl: 2019 Dönem: Güz

This article was checked by Turnitin. Similarity Index 8\%

\footnotetext{
${ }^{1}$ Kocaeli Üniversitesi İletişim Fakültesi, Türkiye, sayimeri@gmail.com, ORCID ID 0000-0002-2250-8900

2 Kocaeli Üniversitesi İletișim Fakültesi, Türkiye, zdondurucu@yahoo.com ORCID ID 0000-0002-2634-1001

${ }^{3}$ Kocaeli Üniversitesi İletişim Fakültesi, Türkiye, bksarac@gmail.com, ORCID ID 0000-0001-6216-9045
}

\section{* Sorumlu yazar}

\section{ÖZ}

İletişim teknolojilerinin gelişmesi ve bilgi toplumuna geçiş sürecinde öne çıkan ebelediyecilik uygulamaları, 21. yüzyılın kamu yönetimine 1şık tutması beklenen yönetişim olgusunun ilkeleri ile doğrudan ilintilidir. Yerel yönetimlerde vatandaş odaklı hizmet ve katılımcı kamu yönetiminin yaygınlaşması açısından kritik önem kazanan e-belediyecilik hizmet ve uygulamaları Türkiye'de 2000'li yılların başından itibaren devlet politikasının bir parçası haline gelmiștir. Yerel yönetim birimleri ilk olarak Yerel Yönetimler Portalı ve Yerel Bilgi Projesi gibi girişimlerle hizmetlerini sanal ortama taşımışlar, ardından e-belediyecilik dönüşümü giderek yaygınlaşmıștır. Öte yandan geçiş sürecinde web sayfaları üzerinden e-belediye hizmetine başlayan ve çeşitli aşamalardan geçerek yeni uygulamalar geliştiren belediyelerin yoğunlaştıkları bilgi aktarımı, sundukları e-hizmet deneyimi ve vatandaş odaklı katılımcı yönetim pratiklerinin farklılık gösterdiği de görülmektedir. Bu çalışmada Marmara Bölgesi Büyükșehir belediyelerinin e-yönetișim çerçevesinde dijital ortamda sundukları e-belediyecilik hizmet ve uygulamalarının karşılaştırmalı olarak analiz edilmesi amaçlanmıștır. Tübitak 1001 SOBAG destekli $117 \mathrm{~K} 012$ no.lu projenin alan araştırması kapsamında yer alan e-belediyecilik uygulamalarının ölçeği doğrultusunda yapılan çalışmanın örneklemini; Kocaeli, İstanbul, Tekirdağ, Balıkesir, Bursa ve Sakarya'dan oluşan Marmara bölgesinin 6 büyükșehir belediyesi oluşturmaktadır. Araştırma kapsamındaki belediyelerin kurumsal web siteleri 3 ay boyunca kayıt altına alınmıs, bulgular 10 yılı askın bir süredir Newark E-Yönetisim Enstitüsü tarafindan yürütülen "Dünya Belediyelerinde Dijital Yönetişim" başlıklı araştırmanın ölçeği çerçevesinde nitel içerik analizi yöntemiyle ölçümlenmiştir. $\mathrm{Bu}$ bağlamda incelenen belediyelerin web siteleri; Güvenlik/Gizlilik Değişkenleri, Yurttaş ve Sosyal Etkileşim ile Operasyonel-Formal-Enformasyonel-Stratejik Beceri Ölçümü başlıklarında toplanan e-belediyecilik hizmetleri kapsamındaki içerik yönünden değerlendirilmiştir. Araştırma sonucunda, Marmara Bölgesi'nde yer alan Büyükşehir belediyeleri, web sayfalarında sağladıkları e-belediyecilik hizmetleri bakımından Newark E-Yönetişim Enstitüsü araştırma ölçeğinde yer alan temel değişkenlere bağlı olarak analiz edilmiş ve bulgular bu eksende tartışılmıştır.

Anahtar Kelimeler: e-belediye, Dijital Yönetişim, Web Sitesi, Katılımcı Yönetim, e-hizmetler 


\title{
Governance in the Digitalized Cities: Comparative Analysis of Marmara Metropolitan Municipalities' E-Municipality Practices
}

\author{
Prof. Dr. İdil Sayımer ${ }^{1 *}$ \\ Res. Asst. Zeynep Benan Dondurucu ${ }^{2}$ \\ Asst. Prof. Dr. Üyesi Banu Küçüksaraç3
}

First received: 25.09 .2019

Accepted: 10.11.2019

\section{Citation:}

IBAD Journal of Social Sciences

Issue: 5

Pages: 420-443

Year: 2019

Session: Fall

This article was checked by Turnitin. Similarity Index $8 \%$

\footnotetext{
${ }^{1}$ Kocaeli Üniversitesi İletişim Fakültesi, Türkiye, sayimeri@gmail.com, ORCID ID 0000-0002-2250-8900

${ }^{2}$ Kocaeli Üniversitesi İletişim Fakültesi, Türkiye, zdondurucu@yahoo.com, ORCID ID 0000-0002-2634-1001

${ }^{3}$ Kocaeli Üniversitesi İletişim Fakültesi, Türkiye, bksarac@gmail.com,

ORCID ID 0000-0001-6216-9045
}

\section{* Corresponding Author}

\begin{abstract}
The e-municipality practices that emerged in the information society process are directly related to the governance principles that are expected to shed light on the public administration of the 21st century. E-municipal services in Turkey has become a part of state policy since the early 2000s, and has won critical importance in the process of citizen-oriented public services and participatory local government management. Local government units first launched their services in a virtual environment through initiatives such as the Local Authorities Portal and Local Information Project, and then the e-municipality transformation became more widespread. On the other hand e-municipality practices differ in the manner of the transfer of information, e-service experience and the citizen-oriented participatory management practices of the municipalities. In this study, it is aimed to analyze comparatively the e-municipality services and applications offered by the metropolitan municipalities of Marmara Region within the framework of egovernance. The study was conducted in accordance with the e-municipality applications scale of the project no. 117K012 supported by TUBITAK 1001 SOBAG. The sample of the study consisted 6 metropolitan municipalities of Marmara region which are Kocaeli, Istanbul, Tekirdag, Balikesir, Bursa and Sakarya. The corporate web sites of the municipalities were recorded for 3 months within the scope of the study, and the findings were measured by qualitative content analysis method scale of the survey titled Dijital Digital Governance in the World Municipalities which has been conducted by Newark E-Governance Institute for more than 10 years. In this context, the websites were evaluated according to emunicipality service headings as; Security/Confidentiality variables, Citizen and Social Interaction, Measurement of Operational-Formal-Informational- and Strategic Skills. As a result, the municipalities were analyzed in terms of the emunicipal services they provided on the web pages based on the basic variables of the research scale of Newark E-Governance Institute and the findings were discussed on this axis.
\end{abstract}

Anahtar Kelimeler: e-municipality, Digital Governance, web sites, Participatory Management, e-service 


\section{GíRIŞ}

Dünyada yaşanan dijital devrim, kamu ve özel sektörün kurumsal işleyişinden toplumsal ve bireysel yaşam pratiklerine kadar her alanda bir dönüşüme neden olmuştur. Özellikle Web 2.0 teknolojilerinin gelişimi ve ortaya çıkan yeni medya ortamlarıyla birlikte kamusal hizmet sunumlarındaki geleneksel merkeziyetçi, hantal ve verimsiz işleyiş modeli terk edilmeye başlanmıştır. Yönetişim kavramının teknoloji ile entegrasyonu kamu hizmetlerine şeffaflık, açıklık, etkileşim, hız, zaman-mekandan bağımsız olma ve katılımcılık unsurlarını taşıyarak yönetimsel değişimin temel unsurlarını oluşturmuşlardır. Kamu yönetimine yansıyan bu teknolojik gelişmelerin en yaygın kullanım biçimlerinden biri devlet hizmetlerini kapsayan e-devlet uygulamalardır. E-devlet ve onun yerel yönetimlerdeki uzantısı olan e-belediyecilik uygulamalarının bilgi ve iletişim teknolojileri aracıllğıyla devlet performansının güçlendirilmesine anlamlı bir katkı sunduğunu da söylemek mümkündür.

E-devlet ve e-belediyecilik gibi interaktif uygulamalar sadece prestij sağlayan ve maliyet azaltan bir kamu hizmetleri sunum şekli olmayıp; profesyonel, akılcı, şeffaf, denetlenebilir, katılımcı ve etkin bir kamu yönetimi anlayışının da temel gerekliliklerindendir. Bu nedenle de, kamu hizmetinin paydaşı olan vatandaşlar başta olmak üzere tüm kamu ve özel hukuk kişiler hatta kamu hizmetini bizzat sunan birimler için zaman, enerji ve insan kaynakları gibi alanlarda tasarruf sağlayarak; maliyetlerin azalmasına, hizmet sunumunun hızlanmasına, hizmete erişimin daha kaliteli ve etkin olmasına katkı sunmaktadır (Mecek, 2018). Ganapathy ve Kumar (2014, s.17) ise; "e-Devlet" kavramının temel hedeflerinden birinin devletin paydaşlarıyla olan etkileşimini arttırmak olduğuna dikkat çekerek, hükümetle vatandaşlar (G2C), devletle kurumlar (G2B), devletle hükümet (G2G) ve hükümetler ile çalışanlar (G2E) arasında dijitalleşme ve e-devlet uygulamaları sayesinde artan etkileşime vurgu yapmaktadırlar.

Türkiye'de e-devlete geçiş sürecinin başlangıcı 1980'li yılların sonunda başlatılan ilk çalışmalar olarak kabul edilmekle birlikte; e-devlet uygulamaları 2000'li y1llara gelindiğinde daha ciddi şekilde devlet politikaları içersinde yer almaya başlamıştır. Nihayet, 2008'de hizmete giren "E-Devlet Kapısı Projesi" ile tüm e-devlet faaliyetlerinin tek merkezden yürütülmeye başlamasıyla ise hızlanmıştır. Bütün bu uygulamalarla, merkezi ve yerel yönetim birimleriyle devletin, hızlı ve düşük maliyetlerle hizmet sunması, bürokratik engellerin asgari düzeylere çekilmesi, kamusal hizmetin kalitesinin artması ve doğal olarak diğer ülkelerle rekabet edebilecek seviyeye ulaşması hedeflenmektedir (Çarıkçı, 2010, s.97). Edevlet çalışmaları başlangıçta bütüncül bir bakış açısı yerine kurumsal düzeydeki yaklaşımlarla gerçekleştirilmiş, kamu kurum ve kuruluşlarının kurumsal süreçlerinin elektronik ortama taşınması ve organizasyon yapılarının güncellenmesi ile çerçevelenmiştir. 2016-2019 ulusal e-devlet stratejisi ve eylem planı ise daha etkin bir dijital dönüşümü hedeflemiş, vatandaş odaklı e-dönüşüm, sosyal ağlar, yönetişim ve şeffaflık ile hesap verebilirlik kavramlarını öne çıkartarak; e-Devlet alanındaki planlama, karar verme ve uygulama süreçlerinde rol oynayan tüm paydaşlar ile devlet arasındaki ilişkilerin yeniden tanımlanmasının gerekliliğini vurgulamıştır (Ulaştırma Denizcilik ve Haberleşme Bakanlığı, 2016).

E-Belediyecilik teknolojik gelişmeler ekseninde yerel halka hızlı hizmet götürmenin ve şeffaflaşmanın temelini oluşturan bir yerel yönetim aracı olarak Türkiye'deki belediyelerde dijital dönüşümle birlikte yaygınlaşmaya başlamıştır. Öte yandan İnternet aracılı̆̆ıyla belediyedeki işlerle ilgili bilgilere ulaşabilme ve kolaylıkla işlem yapabilme olanağına kavuşan yurttaşların İnternet erişimi ve işlem yapabilecek dijital becerilere sahip olmaları da bu konunun bir diğer önemli boyutudur.

Bu çalışmanın amacı Marmara Bölgesi Büyükşehir belediyelerinin sundukları e-belediyecilik hizmet ve uygulamalarının e-yönetişim çerçevesinde karşılaştırmalı olarak analiz etmektir. Örneklem içinde yer alan Kocaeli Büyükșehir belediyesi, Kasım 2017-Ağustos 2019 tarihleri arasında yürütülmüşs olan Tübitak SOBAG 1001destekli 117K012 no.lu projenin alan araştırması kapsamında yer almıştır. Bu araştırmaya ise Kocaeli'nin de içinde yer aldığı Marmara bölgesindeki Büyükşehir belediyeleri dahil edilmiş ve projenin alan araştırmasında kullanılan e-belediyecilik uygulama ölçeği ile Kocaeli dışında; İstanbul, Tekirdağ, Balıkesir, Bursa ve Sakarya'dan oluşan Marmara bölgesinin 6 büyükşehir belediyesi daha analiz edilmiştir. Böylece Marmara bölgesi belediyelerinin e-belediyecilik performansları karşılaştırmalı olarak ortaya konulmaktadır. Araştırma kapsamındaki belediyelerin kurumsal web siteleri 
3 ay boyunca kayıt altına alınmış, bulgular 10 yılı aşkın bir süredir Newark E-Yönetişim Enstitüsü tarafından yürütülen "Dünya Belediyelerinde Dijital Yönetişim" başlıklı araştırmanın ölçeği çerçevesinde nitel içerik analizi yöntemiyle ölçümlenmiştir. Bu bağlamda incelenen belediyelerin web siteleri; Güvenlik/Gizlilik Değişkenleri, Yurttaş ve Sosyal Etkileşim ile Operasyonel-FormalEnformasyonel-Stratejik Beceri Ölçümü başlıklarında toplanan e-belediyecilik hizmetleri kapsamındaki içerik yönünden değerlendirilmiştir.

\section{E-YÖNETIŞSIM YAKLAŞIMI}

Yönetişim, kamu yönetiminde yeniden yapılanmayı, kamu sektörünün, özel sektör ve sivil toplumun gücünden de yararlanarak kalite ve etkinliğini artırmasını sağlamaya dönük yeniden yapılandırma araçlarından biridir (Demirel, 2010, s.65). Göymen (2001, s.6-7), yönetişimin, bilgi ve iletişim teknolojilerinin gelişimi ile yaşanan toplumsal değişim ve dönüşümlere bağlı olarak ortaya çıkan yeni bir kamu yönetimi anlayışının uzantısı olduğunu belirtmektedir. Kamu hizmetlerinde daha etkin ve olumlu bir değişim amaçlayan yönetişim yaklaşımı, yurttaşların da karar verme süreçlerine aktif katılımı ile demokratik ve meşru bir siyasal iktidar sürecini hedeflemektedir. Kamuda yönetişim, yönetim ve karar alma süreçlerinin tüm paydaşların işbirliği ve katılımı ile yapılmakta olduğunu, yöneticilerin uzlaşmac1, saydam, hesap verebilir, etkin ve sorumlu bir yönetim anlayışı içerisinde davrandıklarını ifade etmektedir. Dolayısıyla, yönetim sadece seçimler aracılığı ile seçilmiş bir kesim tarafindan değil; STK'lar, odalar, meslek grupları, özel sektör kuruluşları, üniversiteler gibi çeşitli grupları da süreçlere dahil ederek gerçekleşmektedir. Yönetişim kavramı içerisinde, yönetenlerin aldıkları kararları halka açık bir şekilde almaları, tüm ilgili paydaşları sürece katmaları ve bilgiye dayalı, uzlaşmacı bir yönetim anlayışı sergilemeleri beklenmektedir (TESEV, 2008).

Buna bağlamda e-yönetişimin ise; bilgi toplumunun ürettiği bir kavram olduğunu söylemek mümkündür. Yeni medya ortamları ve yeni iletişim teknolojileri kullanılarak kamu yönetiminin daha şeffaf, katılımcı ve etkileşimli hale gelmesi söz konusu olmuştur. E-yönetişim sürecinde, yeni iletişim teknolojilerinin gelişiminin kamu kurumları ve paydaşlar arasında etkileşim düzeyinin yükselmesine ve ilişkilerin gelişmesine neden olmuştur (Tejasvee vd., 2010, s. 299). Kanungo (2004), e-yönetişim kavramını; bilgi ve iletişim teknolojilerini aktif kullanım çerçevesinde, kamu, yerel yönetim, yurttaşlar, sivil toplum kuruluşları ve özel sektör gibi farklı paydaş grupları arasında bilginin kolayca erişilebildiği ve şeffaflığın uygulamalara temel oluşturduğu bir yapı olarak tanımlamıştır. Gordon (2012, s. 5) ise, kavramın yönetişim politikalarının oluşumu ve sunumu açısından bilgisayar teknolojilerini temele almasına bağlı olarak yeni bir yönetişim sürecinin oluştuğuna vurgu yapmıştır. Dolayısıyla, bilgi ve iletişim teknolojilerinin devletin yürütme organlarının hizmet sunumu amacıyla kullanılması ile ortaya çıkan "e-devlet" uygulamalarının, iş dünyası, yurttaşlar ve devlet arasında daha aktif bir ilişki inşa edilmesi amacı ile demokratik karar alma süreçlerinin yeni iletişim teknolojileri ile desteklenmesini temele alan "e-demokrasi" uygulamalarına ek olarak, "e-katılımcılık" ve "e-iş" gibi değişkenleri de içerisinde bulunduran e-yönetişim sürecinin kamu kurumları ve ilgili paydaş gruplarının ağ üzerinde meydana getirdikleri etkileşimli bir sistem olduğu sonucuna ulaşabilmektedir (Stahl, 2005, s. 5, Lofstedt, 2005, s. 45, Doğan ve Ustakara, 2013). UNESCO (2002), "e-Yönetişimi”, e-Devlet'ten daha geniş bir kavram olarak tarif ederek; toplumun farklı aktörlerinin bilgiye erişimini ve kapasitelerini arttırmak amacıyla BİT'lerin etkin kullanımı olduğunu belirten bir e-yönetişim tanımı yapmakta; aynı zamanda vatandaşları devlet hizmetlerinin karar alma sürecinde yer almaya teşvik etmenin önemini vurgulamaktadır.

Dawes (2008) ise; e-yönetişimin; kamusal hizmet sunumu, kamu yönetimi, demokratik süreçler ve vatandaş-sivil toplum-devlet ve özel sektör arasındaki ilişkilerin güçlendirilmesini desteklemek amacıyla bilgi ve iletişim teknolojilerinin kullanımını içerdiğini belirterek tanımı güçlendirmektedir.

E-yönetişim yaklaşımlarında ise; iki ana model üzerinde durulmaktadır. Bu modellerden birincisi "Devlet-Vatandaş Birlikteliği Modeli"dir. Bu model, yeni iletişim teknolojilerinin yardımı ile siyasal otorite sınırlamalarını ortadan kaldırarak, diyalog ve etkileşimin temel alındığı ve yurttaşların karar verme süreçlerine aktif dahil olduğu bir ağ oluştrmayı amaçlamaktadır. İkinci model ise; "Hizmet Sunum Modeli”dir. Bu modelde, bilginin geleneksel ve tek yönlü akışı yerine; kamu hizmetlerinin 
etkili ve etkin sunumu amacıyla etkileşimli ve tüm paydaşların dahil olduğu bir yönetişim anlayışını temel almaktadır (Mastek, 2005'den aktaran Demirel, 2010, s. 72).

\subsection{E- Belediyecilik Kavramı ve Uygulama Alanları}

E-belediye kavramı da, e-yönetişim yaklaşımıyla ortaya çıkmış uygulamalardan biridir. Belediyelerin hizmet sunumunu elektronik ortama taşımalarından çok daha fazlasını içermekte olup belediyelerle paydaşları arasındaki ilişkileri arttırması, vatandaşların karar alma mekanizmasında yer alma olanakları sunması, şeffaf ve daha demokratik yönetim süreçleri içermesi, dolayısıyla yönetişim olgusunun gereklerini taşıması bakımından ayrı bir öneme sahiptir. Öte yandan e-Belediyeciliğin başarısı belediye çalışanlarının olduğu kadar vatandaşların da bu uygulamaları kullanabilecek teknoloji bilgi ve becerilerine bağlıdır.

Özcan (2003)'ün vurguladığı üzere, bilgi ve iletişim teknolojilerinin gelişimi ile birlikte İnternet ve sosyal medya, tüm kamu kurumları açısından önem kazanmıştır. Bu süreçten etkilenen yerel yönetim birimleri arasında belediyelerde yer almakta olup; e-devlet uygulamalarının bir uzantısı olarak "ebelediyecilik" kavramı ortaya çıkmıştır. E-belediyecilik uygulamaları kesintisiz olarak sağlanan çok sayıda hizmeti kapsamakta olup; ulaşım bilgi sistemlerinden adres bilgi sistemlerine, elektronik borç ödeme ve fatura işlemlerinden emlak vergi bildirimlerine, şikayet ve bilgi taleplerinden nikah işlemlerine, hava ve yol bilgilendirme sistemlerinden işyeri ruhsat işlemlerine ve mezarlık bilgi sistemlerine kadar farklı alanlarda yurttaşlar işlem yapabilmekte ve istedikleri bilgilere kolayca ulaşabilmektedir (Ersöz, 2005; Postacı ve Ayhan, 2013, s.18).

Bilgi iletişim teknolojilerinin gelişimine bağlı olarak yerel yönetimlerin hizmet verme biçimleri de çok yönlü bir biçimde değişim geçirmiş olup; yeni iletişim teknolojileriyle ilintili olarak ortaya çıkan ebelediyecilik kavramı kent yönetiminde bilgi ve iletişim teknolojilerinden yararlanılarak kent ve toplum yararına bilgi üretimi ve etkin bir biçimde yurttaşların hizmetine sunulması olarak tanımlanabilmektedir (Henden, 2005, s.1). E-belediyecilik uygulamalarının temelinde ise kamu kurumları tarafından bilgi ve iletişim teknolojilerinde ortaya çıkan gelişmelerle bağlantı olarak etkin, verimli, kesintisiz, demokratik ve katılımlı bir hizmet sunumu amacı taşıyan elektronik hizmet (ehizmet) uygulamaları yer almaktadır (Mecek, 2017, s.1816). Günümüzde, belediyeler web siteleri aracıllğı ile bilgi dağılımı, yurttaşlar, işletmeler ve sivil toplum ile iletişim kurma, hizmetlerin çevrimiçi sağlanması ve kamu iş akışı süreçlerinin e-yönetişime uygun bir hale getirilmesi gibi faaliyetlerde bulunmaktadır (Waisanen, 2002, s. 6)

Henden ve Henden (2005, s.59), 2000'li yılların başında e-belediyecilik uygulamalarının sağlayabileceği yararları şu şekilde sıralamaktadırlar: yönetim ve karar alma sürecinin şeffaflaşması; hizmette zaman ve mekan sınırlamasının ortadan kalkması; kurum ve yerel halk açısından hizmet maliyetinde düşüş gözlenmesi; paydaş ruhunun ortaya çıkması ve kentlilik bilinci ile yerel halkta katılımcı bir anlayışın gelişmesi; demokratikleşme sürecinde yol alınmış olması; vatandaşın kendi işini kendisinin yapmasından yola çıkarak yerel yönetimlerdeki fazla olabilecek istihdam sorununun ortadan kalkması; katılımcılık ve izlenebilirlik kavramlarının yaygınlaşmasından dolayı verilen hizmet kalitesinde artış olması; e-belediyecilik uygulamalarının sayısı arttıkça, halkın bilgi teknolojilerini kullanımında da artış gözlenmiş olması; hizmet sunumundaki vatandaş odaklı bakış açısı sayesinde halkın yerel yönetimlere olan güveninde artış görülebilmesi.

Belediyelerin İnternet tabanlı hizmetlerini ölçme ve belediye yurttaş etkileşimi tespit etme amacıyla ülkemizde ve dünyada çeşitli araştırmalar gerçekleştirmiştir. Bu uygulamalara örnek olarak; Almanya'da yerel yönetimler ve vatandaşların ekonomik ilişkilerini temel alan "MEDİA@kommwettbewerb" projesi verilebilir. Proje kapsamında, yurttaşların çevrimiçi hizmetlerden yararlanarak ulaşım ödemeleri gerçekleştirmesi, bilgi alması, fatura ödemesi ve dilekçe doldurması gibi çok sayıda uygulamanın zaman ve maliyet tasaarufu sağlanarak gerçekleşmesi sağlanmıştır (Schröder ve Schmalfeld, 2002, s. 182). Delitheou ve Maraki (2010, s.41) ise; Yunanistan'da Atina Belediyesi'nin sağladığı e-yönetişim hizmetlerini analiz ettikleri anket çalışmalarında, katılımcıların \%90'ından fazla bir kısmının belediyenin sağladığı e-hizmetlerden haberdar olduklarını ve bu hizmetleri yararlı buldukları tespit etmiştir. Gallego-Alvarez vd. (2010, s. 
429) ise 81 ülkenin en büyük ölçekli belediyelerini e-belediyecilik hizmetleri temelli olarak analiz ettikleri çalışmalarında ülkesel farklılıklara rağmen, e-yönetişim uygulamalarının gelişme içerisinde olduğunu ortaya koymuştur. Arduini vd. (2013, s. 177) ise; 4000'in üzerinde İtalyan belediyesine yönelik olarak e-yönetişim temelli olarak gerçekleştirdikleri araştırmalarında; e-belediyecilik hizmetlerinin sağlanması açısından teknik, organizasyonel ve çevresel koşuların belirleyici olduğunu ve genel olarak yeni, dinamik ve özelleştirilmiş hizmet sunumuna yönelik bir talep olduğunu ortaya koymuştur. Lethbridge (2015, s. 7) Avrupa Birliği üyesi Almanya, Finlandinya, Danimarka, Estonya, İtalya, İngiltere, Fransa ve Hırvatistan'a yönelik olarak e-devlet uygulamalarını analiz ettiği çalışmasında, yerel ve bölgesel düzeyde hizmet sunumu açısından Almanya ve Danimarka'nın sayısal olarak en yüksek hizmet sağlayan ülkeler olduğunu tespit etmiştir. 2008-2014 y1lları arasında E-Devlet Gelişim İndeski (E- Government Development Index) içerisinde ilk 10 ülke içerisinde yer alan Amerika Birleşik Devletleri'nde ise eyalet bazında e-devlet hizmetleri açısından Utah, New Jersey, North Carolina, Michigan ve Maine eyaletlerinin web sayfaları sundukları e-hizmetlere bağlı olarak ebelediyecilik alanında önemli örnekler olarak ön plana çıkmaktadır. Utah ve Maine eyaletlerine bağlı web sayfaları kolay navigasyon sistemi, çevrimiçi hizmet sunumu, linkler, kişisel verilerin korunması ve kolay kullanım gibi özelliklerle ön plana çıkarken, New Jersey belediyesi içeriğin özelleştirilebilmesi, sayfa ve sekme geçişlerinin kolaylığı gibi özelliklerle e-belediyecilik açısından ABD özelinde başarılı örnekler arasında yer almaktadır. North Carolina dil seçim olanağı, farklı hizmet ve paydaş grupları için renk kodları gibi kullanıcı dostu özelliklere sahipken; Michigan eyaletine ait belediye web sayfasında e-alışveriş ve staj linkleri gibi diğer belediye sayfalarında bulunmayan bazı özel uygulamalar bulunmaktadır (E-Government Development Index: 2014 ve Ogra ve Thwala, 2014, s. 63-64).

Türkiye'de ise yerel yönetimlerin kamu politikaları çerçevesinde "e-yönetişim" uygulamalarının gelişimi açısından Yerelnet ve Yerelbilgi projeleri ön plana çıkmaktadır. Yerel Yönetimler Bilgi Tabanı Projesi (YERELBİLGİ Projesi) Türkiye'de yerel yönetimlerle ilgili tüm verilerin elektronik bir veri tabanı içerisinde toplanmasını ve karar alma mekanizmalarında bu verilerin analitik analizinin dahil olmasını amaçlayan bir çalışmadır. Yerelnet Projesi ise ülke düzeyinde özerk yerel yönetimlerin bilgi ve deneyim paylaşımını hedefleyen ortak bir bilgi havuzu olarak faaliyet göstermektedir (Güler, 2001, s. 3; Nohutçu ve Demirel, 2005, s. 46). Dolayısıyla yaşanan bu gelişmelere bağlı olarak, Türkiye'de e-belediyecilik hizmetlerine yönelik olarak çeşitli araştırmalar gerçekleştirilmiştir. Bu araştırmalara örnek olarak, Sobacı ve Altınok (2011) ise 16 büyükşehir belediyesinin web sayfalarının e-katılım temelli olarak analiz ettikleri içerik analizi çalışması verilebilir. Araştırma sonucunda, e-katılım tabanlı uygulamalar açısından incelenen sayfaların zengin bir içerik sağlamadığı ve belediyelerin web sayfalarının bir tanıtım broşürüne benzer bir yapı taşıdığı tespit edilmiştir. Serenli (2013) ise, Türkiye genelinde 30 büyükşehir belediyesinin web sayfalarını işlevsellik temelli analiz ettiği çalışmasında, belediye web sayfalarının tasarım, içerik ve erişim açısından genel olarak yetersiz olduğu ve e-belediyecilik uygulamaları açısından işlevselliğinin yetersiz kaldığ1 sonucuna ulaşmıştır. Şat (2016) ise; 30 büyükşehir belediyesinin web sitesini analiz ettiği çalışmasında etkileşimli hizmetler konusundan belediyelerin eksikliklerinin olduğunu ve e-belediyecilik uygulamalarının genel olarak ödemeler üzerine yoğunlaştığını tespit etmiştir. Bu bağlamda, Türkiye'de e-belediyecilik uygulamalarına yönelik gerçekleştirilen çalışmalar doğrultusunda, genel olarak e-belediyecilik uygulamalarının hizmet sunumu, katılımcılık ve belediyeyurttaş etkileşimi gibi e-yönetişimin temel kriterlerini sağlama açısından yetersiz kaldığı sonucuna ulaşılmaktadır.

\section{Marmara Bölgesi Büyükşehir Belediyeleri'nin Karşılaştırmalı E-Belediyecilik Uygulamalarına Yönelik Bir Analiz}

Bu çalı̧̧mada, Marmara Bölgesi Büyükşehir Belediyeleri'nin kurumsal web siteleri, Ocak-Mart 2018 dönem aralı̆ğnda karşılaştırılmalı olarak incelenmiştir. Böylece, ilgili belediyelerin web sayfaları aracıllğı ile hizmet sunum biçimlerinin e-yönetişim modelleri çerçevesinde karşılaştırmalı ve keşifsel olarak analiz edilmesi amaçlanmıştır. Bu amaçtan hareketle çalışmanın araştırma sorusu şu şekilde oluşturulmuştur: 
Belediyelerin web sitelerinde sundukları hizmetlerin, "içerik", "kullanılabilirlik", "servisler/hizmetler", "gizlilik/güvenlik", "yurttaş ve sosyal etkileşim" değişkenleri açısından nasıl bir dağılım göstermektedir? $\mathrm{Bu}$ dağılım, e-yönetişim modelleri kapsamında nasıl değerlendirilebilir?

\subsection{Araştırmanın Amacı, Örneklemi ve Sınırıııkları}

$\mathrm{Bu}$ çalışmada, Marmara Bölgesi'nde faaliyet gösteren Büyükşehir Belediyelerinin e-yönetişim bağlamında yeni medya ortamlarında sundukları e-belediyecilik hizmetlerin özelliklerinin e-yönetişim modelleri çerçevesinde karşılaştırmalı olarak analiz edilmesi amaçlanmaktadır. Araştırmada amaçlı örneklem yönteminden yararlanılmıştır. Amaçlı örneklem kullanımı, araştırmacının amacına uygun bir biçimde veri sağlayabileceği bir yada birden fazla özel durumda tercih edilen bir örnekleme biçimi olup; araştırmacının araştırma konusuna bağlı olarak olay ve olguları anlama amacı taşıdığı analizlerde yoğun olarak kullanılmaktadır (Büyüköztürk vd., 2018, s.92-93). Dolayısıyla, Marmara bölgesinde yer alan büyükşehir belediyelerin çalışmaya dahil edilmesinin temel nedeni bölge özelinde büyükşehir belediyelerinin sunduğu e-belediyecilik hizmetlerine yönelik karşıllaştırmalı bir analiz yapılmak istenmesidir. Bu sebeple; 3 ay (Ocak-Mart 2018 dönemi) boyunca ilgili belediyelerin kurumsal web siteleri kayıt altına alınmıştır. Araştırma döneminin bu aralıkla sınırlandırılmasının temel sebebi ise; bu dönemin belediyelerin e-hizmetlerinde bir artış/azalma gerçekleşmesine neden olabilecek (yerel seçimler gibi) herhangi bir zaman dilimine denk gelmemesidir. Araştırma 31 Mart 2019 tarihinde yapılan yerel ve mahalli seçimlerden önce tamamlanmıştır.

\subsection{Araştırmanın Yöntemi, Ölçeği ve Sorusı}

Araştırmanın bulguları; Newark E-Yönetişim Enstitüsü tarafından 10 yılı aşkın bir süredir gerçekleştirilen "Dünya Belediyelerinde Dijital Yönetişim" başlıklı araştırma ve Van Deursen vd. (2014) "Dijital Beceri Sınıflandırması" ölçekleri çerçevesinde nitel içerik analizi yöntemiyle ölçümlenmiştir. Silverman (2001) nitel veri analizi yöntemleri arasında, içerik analizini de dahil etmektedir. İçerik analizi, iletişimin görünen veya yazılı içeriğinin objektif, sistematik bir biçimde belirlenmesidir (Berelson, 1952, s. 56). Yöntem olarak özel prosedürlerden meydana gelmekte olup; araștırmacinın tekniği, içgörüsü ve konuya göre değişiklikler gösterebilmektedir. Ancak gösterdiği bu çeşitliliğe rağmen bilimsel bir yöntem olarak kabul edilen içerik analizi yöntemine bağlı olarak sonuçların güvenilir ve verilerin yorumlanabilir olması beklenmektedir .Içerik analizinde verilerin açık ve anlaşılır olduğu durumlarda, keşifsel veya betimleyici içerik analizi yapılabilmektedir. İçerik analizinde amaç, farklılıkların keşfedilmesi olabilir. Ancak, veri setlerinin büyüklüğü nedeniyle, çözümeleme amacıyla ilgili bulgular kodlara ayrılarak çözümleme gerçekleştirilmektedir. (Krippendorff, 2004, s. 18-19, 5054). İçerik analizinde temel amaç, toplanan verileri açıklayabilecek kavram ve ilişkileri ortaya koymaktır. İçerik analizinde nitel araştırma verileri; verilerin kodlanması, düzenlenmesi, bulguların tanımlanması ve yorumlanması gerçekleştirilmektedir (Yıldırım ve Şimsek, 2018: 242-244). Strauss ve Corbin (1990), içerik analizinde yer alabilecek kodlama biçimleri arasında "daha önceden belirlenmiş kavramlara göre yapılan kodlama" üzerinde durmaktadır. Bu kodlama biçiminde daha önceden araştırmanın temelini oluşturan bir kuram ve kavramsal çerçevenin olduğu durumlarda önceden bir kod listesi çıkartılabilir.

$\mathrm{Bu}$ nedenle, bu çalışmada, Newark E-Yönetişim Enstitüsü tarafindan 10 yılı aşkın bir süredir gerçekleştirilen "Dünya Belediyelerinde Dijital Yönetişim" başlıklı araştırma ölçeğinde yer alan kodlar kullanılmıştır. Kodlama tablosunda yer alan değişkenler, belediye hakkında çeşitli bilgilere, stratejik yönetim sürecine, kamusal belgelere, raporlara, yayınlara ve multimedya materyallerine erişimi kapsayan "içerik"; sayfa uzunluğu, zemin rengi gibi kullanıcı dostu biçimsel özellikleri kapsayan ve web sayfasına erişim, hızlı yüklenme gibi, arama motorunun varlığı gibi işlemlerinin kolayca gerçekleştirilmesini sağlayan fonksiyonel özelliklerden oluşan "kullanılabilirlik"; bilgi edinme başvurusu, çevrimiçi işlemler/ödemeler, borç sorgulama işlemleri, spor, turizm, nikah, konut edinme, kültür sanat gibi farklı alanlara yönelik uygulamaların mevcudiyetini içeren "hizmet/servis"; gizlilik politikalarının mevcudiyeti, kişisel veri paylaşım süreçleri ile ilgili yurttaşın bilgilendirilmesi, kullanıcıların özel profil oluşturup şifre/dijital imza gibi araçlarla işlem yapabilmesi, hesap kurtarma işlemlerinin gerçekleştirilebilmesi gibi uygulmaları kapsayan "gizlilik/güvenlik" ve belediye temsilcilerine e-posta ile erişim, web sayfasının çevrimiçi danışmaya uygunluğu, kent gündemi ile ilgili 
çevrimiçi oylamaların varlığı, dijital hizmet değerlendirme anketlerinin mevcudiyeti gibi değişkenleri kapsayan "yurttaş ve sosyal etkileşim" kategorilerinden meydan gelmektedir. Ayrıca araştırma ölçeği içerisine bu kategorilere ek olarak; Van Deursen vd. (2014) "Dijital Beceri Sinıflandırması" ölçeği çerçevesinde belediyelerin hizmet sunumunun yurttaşların dijital becerilerinin kullanımına uygunluğunun belirlenmesi amaciyla; operasyonel, formal, enformasyonel ve stratejik dijital beceri kategorileri dahil edilmiştir. Araştırmanın kodlama birimleri ise "var, yeterli $(+)$ ", "var, yetersiz $( \pm)$ ", "yok (-)", "belirsiz (?)" olarak oluşturulmuş ve analizler bu yönde gerçekleştirilmiştir.

\subsection{Araştırmanın Bulguları}

Analiz kapsamına alınan web sitelerinin incelenmesinde içerik analizi metodolojisi doğrultusunda tablolamadan yararlanılmıştır. Data setlerinin büyük olduğu ve verilerin karşılaştırılabilir olduğu durumlarda, tablolama sıklıkla kullanılan bir veri analiz yöntemidir. Tablolama, aynı kodlama kategorilerine yer verilen içerik analizlerinde, her bir kodlama biriminde kaç örneğin/ bulgunun yer aldığını belirlemek amacıyla kullanılmaktadır. Tablolama, her bir kategoride yer alan veri setlerini karşılaştırma amacıyla kesin değerler ortaya koyarak karşılaştırma imkanı sunmaktadır (Krippendorf, 2004, s. 192-193). Bu analiz yönteminde hareketle, 6 belediyenin Ocak-Şubat-Mart 2018 tarihleri arasında web sitelerine yönelik gerçekleştirilen nitel içerik analizi bulguları aşağıdaki gibidir:

Tablo 1. Marmara Bölgesi Büyükşehir Belediyelerin Web Sitelerinin İçerik Özelliklerine Yönelik Analiz

\begin{tabular}{|c|c|c|c|c|c|c|c|c|c|}
\hline No & Kategori & 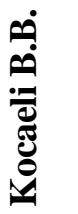 & ف․ & $\stackrel{\mathscr{W}}{\Xi}$ & فी & 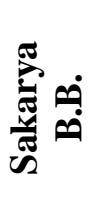 & 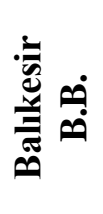 & فه & 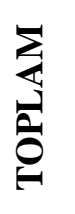 \\
\hline 1 & $\begin{array}{l}\text { Belediye hakkında genel bilgiye } \\
\text { yer verilmiştir. }\end{array}$ & + & + & + & + & + & + & + & 6 \\
\hline 2 & $\begin{array}{l}\text { Belediyenin misyonuna yer } \\
\text { verilmiştir. }\end{array}$ & + & + & + & + & + & + & + & 6 \\
\hline 3 & $\begin{array}{l}\text { Belediyenin vizyonuna yer } \\
\text { verilmiştir. }\end{array}$ & + & + & + & + & + & + & + & 6 \\
\hline 4 & $\begin{array}{l}\text { Belediyenin değerlerine yer } \\
\text { verilmiştir. }\end{array}$ & + & + & + & + & + & + & - & 5 \\
\hline 5 & $\begin{array}{l}\text { Belediyenin tarihçesine yer } \\
\text { verilmiştir. }\end{array}$ & - & + & + & + & + & + & + & 5 \\
\hline 6 & $\begin{array}{l}\text { Belediyenin hedeflerine yer } \\
\text { verilmiştir. }\end{array}$ & + & - & - & - & + & + & + & 4 \\
\hline 7 & $\begin{array}{l}\text { Belediyenin çalışma alanlarına yer } \\
\text { verilmiştir. }\end{array}$ & + & + & + & + & + & + & + & 6 \\
\hline 8 & $\begin{array}{l}\text { Belediyenin teşkilat şemasına yer } \\
\text { verilmiştir. }\end{array}$ & + & + & + & + & + & + & + & 6 \\
\hline 9 & $\begin{array}{l}\text { Belediyenin tüzüğüne yer } \\
\text { verilmiştir. }\end{array}$ & + & + & + & + & + & + & + & 6 \\
\hline 10 & $\begin{array}{l}\text { Belediyenin bütçe ve mali } \\
\text { raporlarına yer verilmiştir. }\end{array}$ & + & + & + & + & + & + & + & 6 \\
\hline 11 & $\begin{array}{l}\text { Belediye meclis, komisyonlar ve } \\
\text { encümenle ilgili bilgilere }\end{array}$ & + & + & + & + & + & + & + & 6 \\
\hline
\end{tabular}




\begin{tabular}{|c|c|c|c|c|c|c|c|c|}
\hline & verilmiştir. & & & & & & & \\
\hline 12 & $\begin{array}{l}\text { Belediye meclis kararlarına yer } \\
\text { verilmiştir. }\end{array}$ & + & + & + & + & + & - & 5 \\
\hline 13 & $\begin{array}{l}\text { Belediye meclisinin ihale vb. idari } \\
\text { alanlarda görüşmeleri ve } \\
\text { kararlarına yönelik canlı yayına ver } \\
\text { verilmiştir. }\end{array}$ & + & - & - & - & - & + & 2 \\
\hline 14 & $\begin{array}{l}\text { Belediyenin stratejik raporları ile } \\
\text { ilgili bilgiye ver verilmiştir. }\end{array}$ & + & - & + & + & + & + & 5 \\
\hline 15 & $\begin{array}{l}\text { Belediyenin stratejik planlaması ile } \\
\text { ilgili bilgiye ver verilmiştir. }\end{array}$ & + & + & + & + & + & + & 6 \\
\hline 16 & $\begin{array}{l}\text { Belediye başkanı ilgili bilgiye yer } \\
\text { verilmiştir. }\end{array}$ & + & + & + & + & + & + & 6 \\
\hline 17 & $\begin{array}{l}\text { Belediye başkanın herhangi bir } \\
\text { konu ile ilgili yaptığı açılamalara } \\
\text { ve mesajlara yer verilmiştir. }\end{array}$ & + & - & + & + & + & + & 5 \\
\hline 18 & $\begin{array}{l}\text { Belediyenin kurumsal yayınlarına } \\
\text { yer verilmiştir (Dergi, Broşür, } \\
\text { makale,rapor vs.) }\end{array}$ & + & + & + & + & + & + & 6 \\
\hline 19 & $\begin{array}{l}\text { Fotoğraf/video ve ses dosyası gibi } \\
\text { multimedya içeriğine yer } \\
\text { verilmiştir. }\end{array}$ & + & + & + & + & + & + & 6 \\
\hline 20 & $\begin{array}{l}\text { Belediyenin gerçekleştirdiği } \\
\text { etkinliklere yer verilmiştir. }\end{array}$ & + & + & + & + & + & + & 6 \\
\hline 21 & $\begin{array}{l}\text { Belediyenin basın arşivine yer } \\
\text { verilmiştir. }\end{array}$ & - & + & + & + & + & + & 5 \\
\hline 22 & $\begin{array}{l}\text { Belediyenin etkinlik takvimine yer } \\
\text { verilmiştir. }\end{array}$ & + & - & + & + & + & + & 5 \\
\hline 23 & $\begin{array}{l}\text { Belediyenin etkinlik duyurularına } \\
\text { yer verilmiştir. }\end{array}$ & + & + & + & + & + & + & 6 \\
\hline 24 & $\begin{array}{l}\text { İl /ilçe ile ilgili tanıtıcı bilgiye yer } \\
\text { verilmiştir }\end{array}$ & + & + & + & + & - & + & 5 \\
\hline 25 & $\begin{array}{l}\text { Belediyenin sosyal medya } \\
\text { hesaplarına link verilmiş/isimleri } \\
\text { verilmiştir. }\end{array}$ & \pm & + & + & + & + & + & 5 \\
\hline 26 & $\begin{array}{l}\text { Belediyenin güncel iletişim } \\
\text { bilgilerine yer verilmiştir. }\end{array}$ & + & + & + & + & + & + & 6 \\
\hline 27 & $\begin{array}{l}\text { Belediyenin raporları, yayınları vb. } \\
\text { ile ilgili indirilebilir dokümanlara } \\
\text { yer verilmiştir. }\end{array}$ & + & + & + & + & + & + & 6 \\
\hline \multicolumn{2}{|c|}{$\begin{array}{ll}\text { TOPLAM } \\
\end{array}$} & 24 & 22 & 25 & 26 & 25 & 25 & \\
\hline
\end{tabular}

Belediyelerin web siteleri, belediye hakkında çeşitli bilgilere, stratejik yönetim sürecine, kamusal belgelere, raporlara, yayınlara ve multimedya materyallerine erişimi kapsayan içerik özellikleri 
açısından; belediye hakkında genel bilgi (vizyon, misyon, değerler), kurumsal raporlar/yayınlar, iletişim bilgileri gibi 27 içeriksel değişken bağlamında analiz edilmiştir.

Tablo-1'e göre, Marmara Büyükşehir belediyeleri arasında Sakarya Büyükşehir Belediyesi web sitesinde 26 değişkene yer vererek içeriksel anlamda en fazla bilgiyi barındıran belediye olarak karşımıza çıkmaktadır. Sakarya Büyükşehir Belediyesi'ni, 25 değişkenle Bursa, Balıkesir ve Tekirdağ Büyükşehir Belediyeleri takip etmektedir. Ardından web sitesinde içeriksel bilgilere yer vermesi açısından 24 değişkenle Kocaeli Büyükşehir Belediyesi'nin geldiği tespit edilmiş olup; sayfasında içeriksel anlamda en az bilgi barındıran belediyenin ise 22 değişkenle İstanbul Büyükşehir Belediyesi olduğu görülmektedir.

Analiz kapsamında belediyelerin web sitelerinde yüksek, orta ve düşük düzeyde yer verdikleri içerik özellikleri incelenmiştir. Bu bağlamda; Marmara Bölgesi Büyükşehir Belediyeleri'nin web sitelerinde en fazla yer verdikleri değişkenlerin, belediye hakkında genel bilgi, misyon, vizyon, belediyenin çalışma alanları, teşkilat şeması, tüzüğü, bütçe/mali raporları, belediye meclisi/komisyonları ile ilgili bilgiler, stratejik planlamaları, belediye başkanı ile ilgili bilgi, etkinlikler/etkinlik duyurumları, güncel iletişim bilgileri, indirilebilir dökümanlar, multimedya dosyaları olduğu tespit edilmiştir. Orta düzeyde yer verdikleri içeriksel değişkenlerin ise; il ve ilçe ile ilgili tanıtıcı bilgiler, resmi sosyal medya hesaplarının isim ve linkleri, basın arşivi, etkinlik takvimi, belediye başkanının açıklamaları, stratejik raporlar, meclis kararları, belediyenin tarihçesi ve değerleri olduğu sonucuna ulaşılmıştır. Marmara Bölgesi Büyükşehir Belediyeleri'nin web sayfalarında inceleme döneminde en düşük sayıda tespit edilen değişkenlerin ise; belediye ihalelerine ve görüşmelerine yönelik canlı yayınlar ve belediyelerin hedefleri olduğu sonucuna ulaşılmıştır. Bu bağlamda araştırma sonucunda, Marmara Bölgesi Büyükşehir Belediyeleri'nin web sayfalarının sahip olduğu içeriksel özelliklerin farklılık gösterdiği tespit edilmekle birlikte; inceleme kapsamına alınan belediyelerin web sayfalarının yurttaş erişimine imkan sağlayacak düzeyde ve nitelikte içeriksel bilgi içerdiği değerlendirmesinde bulunulabilir.

Tablo 2. Marmara Büyükşehir Belediyeleri’nin Web Sitelerinin Kullanılabilirlik Özelliklerine Yönelik Analiz

\begin{tabular}{|c|c|c|c|c|c|c|c|c|}
\hline No & Kategori & 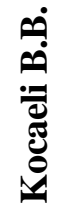 & فी & 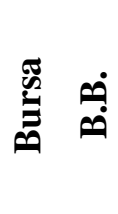 & فी & ف을 & فी & $\sum_{\substack{a \\
\hat{\sigma}}}$ \\
\hline 1 & $\begin{array}{l}\text { Belediyenin kurumsal renklerine yer } \\
\text { verilmiştir. }\end{array}$ & + & + & + & + & + & + & 6 \\
\hline 2 & $\begin{array}{l}\text { Zemin rengi sade ve anlaşılır } \\
\text { yapıdadır. }\end{array}$ & + & + & + & + & - & + & 5 \\
\hline 3 & $\begin{array}{l}\text { Türkçe karakter kullanımına } \\
\text { uygundur. }\end{array}$ & + & + & + & + & + & + & 6 \\
\hline 4 & $\begin{array}{l}\text { Kullanılan yazı fontu ve büyüklüğü } \\
\text { rahat okunmaya elverişlidir. }\end{array}$ & + & + & + & \pm & + & + & 5 \\
\hline 5 & Sayfa uzunluğu optimal ölçüdedir. & + & - & + & - & - & - & 2 \\
\hline 6 & $\begin{array}{l}\text { Sayfa kenar boşlukları optimal } \\
\text { ölçüdedir. }\end{array}$ & + & - & + & + & \pm & + & 4 \\
\hline 7 & Siteye erişim kolaylığı vardır. & + & + & + & + & + & + & 6 \\
\hline 8 & $\begin{array}{l}\text { Web sayfasının linki ve belediyenin } \\
\text { ismi bağlantılıdır. }\end{array}$ & + & + & + & + & + & + & 6 \\
\hline 9 & Web sayfası kısa zamanda/hızlı & + & + & + & + & + & + & 6 \\
\hline
\end{tabular}




\begin{tabular}{|c|c|c|c|c|c|c|c|c|}
\hline & yüklenmektedir. & & & & & & & \\
\hline $\mathbf{1 0}$ & $\begin{array}{l}\text { Web sayfasında site haritas } 1 \\
\text { bulunmaktadır. }\end{array}$ & + & + & + & - & + & + & 5 \\
\hline 11 & $\begin{array}{l}\text { Web sayfasının içerisinde arama } \\
\text { motoru vardır. }\end{array}$ & + & + & + & - & + & - & $\overline{4}$ \\
\hline 12 & $\begin{array}{l}\text { Web sayfasının içerisinde bulunan } \\
\text { bağlantı linklerine doğru ve hızlı bir } \\
\text { biçimde erişilmektedir. }\end{array}$ & + & + & + & + & \pm & + & 4 \\
\hline 13 & $\begin{array}{l}\text { Üç tık kuralı ile istenen bilgiye } \\
\text { ulaşılmaktadır. }\end{array}$ & + & + & + & + & + & + & 6 \\
\hline 14 & $\begin{array}{l}\text { Web sayfasında kayma, } \\
\text { karakterlerin, görsel öğelerin } \\
\text { karmaşılı̆̆ı gibi bir sorun yoktur. }\end{array}$ & + & + & + & + & + & + & 6 \\
\hline 15 & $\begin{array}{l}\text { Sayfa çıktı alınmasına uygun bir } \\
\text { yapıdadır. }\end{array}$ & + & + & + & + & + & + & 6 \\
\hline 16 & Dil seçim olanağı vardır. & + & + & + & + & + & - & 5 \\
\hline 17 & $\begin{array}{l}\text { Web sayfası mobil cihazlardan } \\
\text { yüklenmeye uygun bir yapıdadır. }\end{array}$ & + & + & + & + & + & + & 6 \\
\hline 18 & $\begin{array}{l}\text { Web sayfasında çevrimiçi formlar } \\
\text { bulunmaktadır. }\end{array}$ & + & + & + & + & + & + & 6 \\
\hline 19 & $\begin{array}{l}\text { Web sayfasında bulunan çevrimiçi } \\
\text { formlar kolayca doldurulabilir bir } \\
\text { yapıdadır. }\end{array}$ & + & + & + & + & - & + & 5 \\
\hline 20 & $\begin{array}{l}\text { Web sayfasında yer alan bilgiler } \\
\text { düzenli olarak güncellenmektedir. }\end{array}$ & + & + & + & + & + & + & 6 \\
\hline 21 & $\begin{array}{l}\text { Web sayfasında navigasyon hizmeti } \\
\text { bulunmaktadır. }\end{array}$ & + & + & + & + & - & + & 5 \\
\hline 22 & $\begin{array}{l}\text { Web sayfası engelli girişine } \\
\text { uyumludur. }\end{array}$ & - & - & - & - & - & - & $\mathbf{0}$ \\
\hline \multicolumn{2}{|r|}{ TOPLAM } & 21 & 19 & 21 & 17 & 15 & 18 & \\
\hline
\end{tabular}

Belediyelerin web sitelerinin kullanılabilirlik düzeyleri; sayfa uzunluğu, zemin rengi gibi kullanıcı dostu biçimsel özellikleri kapsayan ve web sayfasına erişim, hızlı yüklenme gibi, arama motorunun varlı̆ğ gibi arama işlemlerinin kolayca gerçekleştirilmesini sağlayan fonksiyonel özelliklerden oluşan 22 kullanılabilirlik değişkeni çerçevesinde analiz edilmiştir.

Tablo-2'ye göre, Marmara Bölgesi Büyükșehir Belediyeleri arasında Kocaeli Büyükșehir Belediyesi ile Bursa Büyükşehir Belediyeleri web sitesinde kullanılabilirlik düzeyi en yüksek olan belediyeler olarak karşımıza çıkmaktadır. Bu belediyeleri 19 değişkenle İstanbul Büyükşsehir Belediyesi, 18 değişkenle Tekirdağ Büyükşehir Belediyesi ve 17 değişkenle Sakarya Büyükşehir Belediyesi takip etmektedir. Web sitesinde kullanılabilirlik düzeyi en düşük olan belediyenin ise 15 değişkenle Balıkesir Büyükşehir Belediyesi olduğu sonucuna ulaşılmıştır.

Analiz kapsamında belediyelerin web sitelerinde yüksek, orta ve düşük düzeyde yer verdikleri kullanılabilirlik değişkenleri de incelenmiştir. Bu bağlamda; Marmara Bölgesi Büyükşehir Belediyeleri'nin web sitelerinde en fazla yer verdikleri değişkenlerin kurumsal renklerin kullanımı, Türkçe karakter kullanımına uygunluk, erişim kolaylığı, belediye linki ve isminin bağlantılı olması, web 
sayfasının kısa zamanda ve hızlı yüklenebilmesi, üç tık kuralı ile bilgiye kolay erişim, web sitesinde kayma ve görsel kargaşa bulunmaması, sayfanın çıktı almaya uygun bir yapıda olması, mobil cihazlarla uyum, sayfada çevrimiçi formların bulunması ve bilgilerin düzenli olarak güncellenmesi olduğu sonucuna ulaşılmıştır. Orta düzeyde yer verdikleri kullanılabilirlik değişkenlerin ise; zemin renginin sade ve anlaşılabilir bir yapıda olması, yazı fontu ve büyüklügünün okumaya elverişliliği, sayfa kenar boşluklarının optimal ölçüde olması, site içerisinde harita/arama motoru/navigasyon hizmetlerinin bulunması, bağlantı linklerine doğru ve hızlı erişim, dil seçim olanağının mevcudiyeti, çevrimiçi formların kolayca doldurulabilmesi özellikleri olduğu tespit edilmiştir. Marmara Bölgesi Büyükşehir Belediyeleri'nin web sayfalarında inceleme döneminde en düşük sayıda tespit edilen değişkenin ise; sayfa uzunluğunun optimal ölçüde olması olduğu sonucuna ulaşılmıştır. Bu özelliğe sahip sadece iki belediye bulunmakta olup; bunlar Kocaeli ve Bursa Büyükşehir Belediyeleri'dir. Ayrıca, araştırma sonucunda belediyelerin kullanılabilirlik özellikleri açısından web sitelerinde hiç yer vermedikleri özelliğin ise, web sitesinin engelli girişine uyumlu olması olduğu tespit edilmiştir.

Bu bağlamda araştırma sonucunda, Marmara Bölgesi Büyükşsehir Belediyeleri’nin web sayfalarının sahip olduğu kullanılabilirlik özelliklerin farklılık gösterdiği tespit edilmekle birlikte; belediyeler arasında çok büyük farklılıklar tespit edilmemiştir. Dolayısıyla, Marmara Büyükşehir Belediyelerinin web sitelerinde kullanılabilirlik özelliklerini büyük oranda sağladıkları değerlendirmesi yapılabilir. Ancak, iki belediye hariç sayfa uzunluklarının optimal ölçüde olmaması; kullanım açısından yurttaşlara problem oluşturabilecek bir eksiklik olarak değerlendirilebilir. Ayrıca, araştırma sonucunda Marmara Bölgesi Büyükşehir Belediyeleri'nin web sayfalarında tespit edilen en temel eksiklik; e-yönetişim pratikleri bağlamında tüm paydaş gruplarla etkileşim içerisinde olması gereken belediyelerin sitelerinin engelli girişine uyumlu olmamasıdır. Bu durum, belediyelerin hizmet sunumu gerçekleştirmesi gereken temel hedef dezavantajlı gruplar arasında yer alan engelli yurttaşların dijital olarak belediyeden hizmet almasını engelleyen önemli bir problem olarak değerlendirilebilir.

Tablo 3. Marmara Bölgesi Büyükşehir Belediyelerinin Web Sitelerinin/E-Belediyecilik Sayfalarının Servis/Hizmet Özelliklerine Yönelik Analiz

\begin{tabular}{|c|c|c|c|c|c|c|c|c|}
\hline No & Kategori & فी & فํ. & 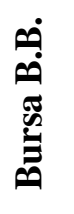 & فी & فص & فำ & 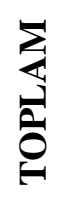 \\
\hline 1 & $\begin{array}{l}\text { Web sayfası ve/veya e-belediyecilik } \\
\text { sayfasında bilgi edinme başvuru } \\
\text { sayfası bulunmaktadır. }\end{array}$ & + & + & + & + & + & \pm & 5 \\
\hline 2 & $\begin{array}{l}\text { Web sayfası ve/veya e-belediyecilik } \\
\text { sayfasında borç sorgulama hizmeti } \\
\text { bulunmaktadır. }\end{array}$ & + & + & \pm & + & + & - & 4 \\
\hline 3 & $\begin{array}{l}\text { Web sayfası ve/veya e-belediyecilik } \\
\text { sayfasında herhangi bir hizmet alanı } \\
\text { ile ilgili izin başvurusu yapılmaktadır. }\end{array}$ & + & + & + & + & + & - & 5 \\
\hline 4 & $\begin{array}{l}\text { Web sayfası ve/veya e-belediyecilik } \\
\text { sayfasında çevrimiçi işlem takip } \\
\text { sistemi bulunmaktadır. }\end{array}$ & + & + & + & - & + & - & 4 \\
\hline 5 & $\begin{array}{l}\text { Web sayfası ve/veya e-belediyecilik } \\
\text { sayfasında herhangi bir konuda } \\
\text { doldurulabilecek çevrimiçi şikayet } \\
\text { formu yer almaktadır. }\end{array}$ & + & + & + & + & + & + & 6 \\
\hline
\end{tabular}




\begin{tabular}{|c|c|c|c|c|c|c|c|c|}
\hline 6 & $\begin{array}{l}\text { Web sayfası ve/veya e-belediyecilik } \\
\text { sayfasında herhangi bir konuda } \\
\text { doldurulabilecek çevrimiçi dilek, istek } \\
\text { ve talep formu yer almaktadır. }\end{array}$ & + & - & + & + & + & + & 5 \\
\hline 7 & $\begin{array}{l}\text { Web sayfası ve/veya e-belediyecilik } \\
\text { sayfasında cezalar ve vergiler ile ilgili } \\
\text { çevrimiçi ödeme yapılmasını sağlayan } \\
\text { bir sistem bulunmaktadır. }\end{array}$ & + & - & + & + & + & - & 4 \\
\hline 8 & $\begin{array}{l}\text { Web sayfası ve/veya e-belediyecilik } \\
\text { sayfasında ulaşım hizmetlerine } \\
\text { yönelik e-belediyecilik hizmetleri } \\
\text { bulunmaktadır. }\end{array}$ & + & + & + & + & + & + & 6 \\
\hline 9 & $\begin{array}{l}\text { Web sayfası ve/veya e-belediyecilik } \\
\text { sayfasında kültür ve sanat } \\
\text { hizmetlerine yönelik e-belediyecilik } \\
\text { hizmetleri bulunmaktadır }\end{array}$ & \pm & + & + & + & + & + & 5 \\
\hline 10 & $\begin{array}{l}\text { Web sayfası ve/veya e-belediyecilik } \\
\text { sayfasında Meslek ve beceri } \\
\text { kazandırmaya yönelik e-belediyecilik } \\
\text { hizmetleri bulunmaktadır. }\end{array}$ & + & - & - & - & - & + & 2 \\
\hline 11 & $\begin{array}{l}\text { Web sayfası ve/veya e-belediyecilik } \\
\text { sayfasında su ve kanalizasyon } \\
\text { hizmetlerine yönelik e-belediyecilik } \\
\text { hizmetleri bulunmaktadır. }\end{array}$ & - & \pm & - & + & + & - & 2 \\
\hline 12 & $\begin{array}{l}\text { Web sayfası ve/veya e-belediyecilik } \\
\text { sayfasında sosyal hizmetler ve yardım } \\
\text { hizmetlerine yönelik e-belediyecilik } \\
\text { hizmetleri bulunmaktadır. }\end{array}$ & - & + & + & + & + & + & 5 \\
\hline 13 & $\begin{array}{l}\text { Web sayfası ve/veya e-belediyecilik } \\
\text { sayfasında çevre hizmetlerine yönelik } \\
\text { e-belediyecilik hizmetleri } \\
\text { bulunmaktadır. }\end{array}$ & - & + & + & + & + & + & 5 \\
\hline 14 & $\begin{array}{l}\text { Web sayfası ve/veya e-belediyecilik } \\
\text { sayfasında sağllk ve temizlik } \\
\text { hizmetlerine yönelik e-belediyecilik } \\
\text { hizmetleri bulunmaktadır. }\end{array}$ & - & + & + & + & + & + & 5 \\
\hline 15 & $\begin{array}{l}\text { Web sayfası ve/veya e-belediyecilik } \\
\text { sayfasında arama ve kurtarma } \\
\text { hizmetlerine yönelik e-belediyecilik } \\
\text { hizmetleri bulunmaktadır. }\end{array}$ & - & + & + & - & + & + & 4 \\
\hline 16 & $\begin{array}{l}\text { Web sayfası ve/veya e-belediyecilik } \\
\text { sayfasında turizm ve tanıtım } \\
\text { hizmetlerine yönelik e-belediyecilik } \\
\text { hizmetleri bulunmaktadır. }\end{array}$ & - & + & + & + & + & + & 5 \\
\hline 17 & $\begin{array}{l}\text { Web sayfası ve/veya e-belediyecilik } \\
\text { sayfasında konut edinme, imar ve } \\
\text { istimlak hizmetlerine yönelik e- }\end{array}$ & + & + & + & + & + & + & 6 \\
\hline
\end{tabular}




\begin{tabular}{|c|c|c|c|c|c|c|c|c|}
\hline & $\begin{array}{l}\text { belediyecilik hizmetleri } \\
\text { bulunmaktadır. }\end{array}$ & & & & & & & \\
\hline 18 & $\begin{array}{l}\text { Web sayfası ve/veya e-belediyecilik } \\
\text { sayfasında coğrafi ve kent bilgi } \\
\text { sistemleri hizmetlerine yönelik e- } \\
\text { belediyecilik hizmetleri } \\
\text { bulunmaktadır. }\end{array}$ & + & + & + & + & + & + & 6 \\
\hline 19 & $\begin{array}{l}\text { Web sayfası ve/veya e-belediyecilik } \\
\text { sayfasında defin ve mezarliklar } \\
\text { hizmetlerine yönelik e-belediyecilik } \\
\text { hizmetleri bulunmaktadır }\end{array}$ & + & + & + & + & + & - & 5 \\
\hline 20 & $\begin{array}{l}\text { Web sayfası ve/veya e-belediyecilik } \\
\text { sayfasında itfaiye hizmetlerine yönelik } \\
\text { e-belediyecilik hizmetleri } \\
\text { bulunmaktadır. }\end{array}$ & - & + & + & + & + & + & 5 \\
\hline 21 & $\begin{array}{l}\text { Web sayfası ve/veya e-belediyecilik } \\
\text { sayfasında istihdam ve gelir } \\
\text { hizmetlerine yönelik e-belediyecilik } \\
\text { hizmetleri bulunmaktadır. }\end{array}$ & - & + & \pm & + & + & - & 3 \\
\hline 22 & $\begin{array}{l}\text { Web sayfası ve/veya e-belediyecilik } \\
\text { sayfasında nikâh hizmetlerine yönelik } \\
\text { e-belediyecilik hizmetleri } \\
\text { bulunmaktadır. }\end{array}$ & - & + & - & - & + & - & 2 \\
\hline 23 & $\begin{array}{l}\text { Web sayfası ve/veya e-belediyecilik } \\
\text { sayfasında gerçek ve tüzel kişiler için } \\
\text { izin ve ruhsatlarla ilgili e-belediyecilik } \\
\text { hizmetleri bulunmaktadır. }\end{array}$ & + & - & - & + & + & - & 3 \\
\hline 24 & $\begin{array}{l}\text { Web sayfası ve/veya e-belediyecilik } \\
\text { sayfasında spor hizmetlerine yönelik } \\
\text { e-belediyecilik hizmetleri } \\
\text { bulunmaktadır. }\end{array}$ & - & + & + & + & + & + & 5 \\
\hline 25 & $\begin{array}{l}\text { Web sayfası ve/veya e-belediyecilik } \\
\text { sayfasında vatandaşa yönelik diğer } \\
\text { hizmet alanlarına yönelik e- } \\
\text { belediyecilik hizmetleri } \\
\text { bulunmaktadır. }\end{array}$ & \pm & + & + & - & + & - & 3 \\
\hline & TOPLAM & 13 & 20 & 19 & 20 & 24 & 14 & \\
\hline
\end{tabular}

Belediyelerin web siteleri ve/veya e-belediyecilik sayfalarında başta yurttaşlar olmak üzere çeşitli paydaş gruplara yönelik sundukları hizmetleri içeren servis/hizmetlerin özellikleri, bilgi edinme başvurusu, çevrimiçi işlemler ve ödemeler, borç sorgulama işlemleri, spor, turizm, nikah, konut edinme, kültür sanat gibi farklı alanlara yönelik uygulamaların mevcudiyeti gibi 25 hizmet/servis değişkeni bağlamında analiz edilmiştir.

Tablo-3'e göre, Marmara Bölgesi Büyükşsehir Belediyeleri arasında Balıkesir Büyükşehir Belediyesi web sitesinde ve/veya e-belediyecilik sayfasında 24 değişkene yer vererek en fazla servis/hizmeti sağlayan belediye olarak tespit edilmiştir. Balıkesir Büyükşehir Belediyesi'ni, 20 değişkenle Sakarya ve İstanbul; 19 değişkenle ise Bursa Büyükşehir Belediyesi takip etmektedir. Web sitesinde ve/veya e-belediyecilik 
sayfasında en az servis/hizmet özelliğine sahip olan iki belediyenin ise 14 değişkenle Tekirdağ Büyükşehir ve 13 değişkenle Kocaeli Büyükşehir Belediyeleri olduğu sonucuna ulaşılmıştır.

Analiz kapsamında belediyelerin web sitelerinde yüksek, orta ve düşük düzeyde yer verdikleri hizmet/servis değişkenleri de incelenmiştir. Bu bağlamda; Marmara Bölgesi Büyükşehir Belediyeleri'nin web sitelerinde en fazla yer verdikleri değişkenlerin çevrimiçi şikayet formlarının mevcudiyeti, ulaşım, konut, imar-istimlak, kent bilgi sistemleri alanlarında sunulan hizmetler olduğu sonucuna ulaşılmıştır. Orta düzeyde yer verdikleri hizmet/servis değişkenlerinin ise; çevrimiçi bilgi edinme/izin başvurusu yapılabilmesi, dilek/istek/talep formlarının mevcudiyeti, borç sorgulama/işlem takip/ödeme sistemlerinin varlığı, kültür sanat, sosyal hizmetler, çevre, sağlık/temizlik, turizm/tanıtım, defin/mezarlıklar, arama kurtarma itfaiye ve spor kategorilerinde sağlanan hizmetler olduğu tespit edilmiştir. Marmara Bölgesi Büyükşehir Belediyeleri'nin web sayfalarında inceleme döneminde en düşük sayıda tespit edilen değişkenlerin ise; meslek/beceri kazandırma, su/kanalizasyon, istihdam sağlama, nikah, ruhsat/izin ve diğer hizmetler alanlarında yer aldığı sonucu elde edilmiştir.

Bu bağlamda araştırma sonucunda, Marmara Bölgesi Büyükşehir Belediyeleri’nin web sayfalarının/ebelediyecilik uygulamalarının içerdiği servis/hizmet özelliklerinin anlamlı farklar gösterdiği tespit edilmiştir. Özellikle sağlanan çevrimiçi hizmetler açısından incelenen altı belediye arasında sayısal olarak önemli farklar tespit edilmiştir. Genel olarak araştırma sonuçları değerlendirildiğinde ise, Marmara Bölgesi Büyükşehir Belediyeleri'nin çevrimiçi hizmet sunumu açısından ulaşım, konut, imaristimlak, kent bilgi sistemleri gibi alanlara yoğunlaştı̆̆ı; çevrimiçi borç sorgulama/dilek, istek, talep, şikayet formu doldurma, ödeme, işlem takibi gibi alanlara önem verdiği ancak yurttaş için öne taşıyan mesleki bilgi ve beceri kazanımı, istihdam, ruhsat ve izin alma süreçlerinin yönetimi gibi alanlarda ise dijital hizmet sunumunun yeterli olmadığı yorumunda bulunulabilir.

Tablo 4. Marmara Bölgesi Büyükşehir Belediyelerinin Web Sitelerinin/E-Belediyecilik Sayfalarının Gizlilik/Güvenlik Özelliklerine Yönelik Analiz

\begin{tabular}{|c|c|c|c|c|c|c|c|c|}
\hline No & Kategori & فी & فํ. & فी & فำ & فी & فी & $\sum_{\substack{1\\
}}^{\sum_{1}}$ \\
\hline 1 & $\begin{array}{l}\text { Web sayfası ve/veya e-belediyecilik } \\
\text { sayfasında gizlilik/güvenlik } \\
\text { politikasıyla ilgili bilgiler } \\
\text { bulunmaktadır. }\end{array}$ & - & - & + & - & - & - & 1 \\
\hline 2 & $\begin{array}{l}\text { Web sayfası ve/veya e-belediyecilik } \\
\text { sayfasında gizlilik/güvenlik } \\
\text { politikasını onaylama butonu } \\
\text { bulunmaktadır. }\end{array}$ & - & - & + & - & - & - & 1 \\
\hline 3 & $\begin{array}{l}\text { Web sayfası ve/veya e-belediyecilik } \\
\text { sayfasında kişisel verilerin üçüncü } \\
\text { şahıslarla paylaşımına izin verildiği ile } \\
\text { ilgili bilgiler bulunmaktadır. }\end{array}$ & - & - & - & - & - & - & $\mathbf{0}$ \\
\hline 4 & $\begin{array}{l}\text { Web sayfası ve/veya e-belediyecilik } \\
\text { sayfasında kişisel verilerin üçüncü } \\
\text { şahıslarla paylaşımına izin verilmediği } \\
\text { ile ilgili bilgiler bulunmaktadır. }\end{array}$ & - & - & - & - & - & - & $\mathbf{0}$ \\
\hline 5 & $\begin{array}{l}\text { Web sayfası ve/veya e-belediyecilik } \\
\text { sayfasında kullanıcı adı ve şifrem ile } \\
\text { profil olușturulup ișlem }\end{array}$ & + & + & + & + & + & + & 6 \\
\hline
\end{tabular}




\begin{tabular}{|c|c|c|c|c|c|c|c|c|}
\hline & yapılabilmektedir. & & & & & & & \\
\hline 6 & $\begin{array}{l}\text { Web sayfası ve/veya e-belediyecilik } \\
\text { sayfasında dijital imza sistemi ile } \\
\text { profil oluşturup işlem } \\
\text { yapılabilmektedir. }\end{array}$ & - & - & - & - & + & - & 1 \\
\hline 7 & $\begin{array}{l}\text { Web sayfası ve/veya e-belediyecilik } \\
\text { sayfasında güvenlik doğrulama sistemi } \\
\text { ile hesap kurtarma ve profil kontrol } \\
\text { işlemi yapılabilmektedir. }\end{array}$ & + & + & + & + & + & + & 6 \\
\hline 8 & $\begin{array}{l}\text { Web sayfası ve/veya e-belediyecilik } \\
\text { sayfasında 3D Secure (3D Güvenlik) } \\
\text { hizmeti bulunmaktadır. }\end{array}$ & $?$ & $?$ & $?$ & $?$ & $?$ & $?$ & $\mathbf{0}$ \\
\hline & TOPLAM & 2 & 2 & 4 & 2 & 3 & 2 & \\
\hline
\end{tabular}

Belediyelerin web sitelerinde ve/veya e-belediyecilik sayfalarında gizlilik/güvenlik özellikleri; gizlilik politikalarının mevcudiyeti, kişisel veri paylaşım süreçleri ile ilgili yurttaşın bilgilendirilmesi, kullanıcıların özel profil oluşturup şifre/dijital imza gibi araçlarla işlem yapabilmesi, hesap kurtarma işlemlerinin gerçekleştirilebilmesi, işlemlerde 3D güvenlik hizmetlerinin varlığı gibi 8 değişken üzerinden analiz edilmiştir.

Tablo-4'e göre, Marmara Büyükşehir Belediyeleri arasında Bursa Büyükşehir Belediyesi 4 değişkenle web sitesinde ve/veya e-belediyecilik sayfasında gizlilik/güvenlik özelliklerini en fazla sağlayan belediye olarak karşımıza çıkmaktadır. Bursa Büyükșehir Belediyesi’ni 3 değișkenle Balıkesir Büyükșehir Belediyesi takip etmekte olup; 2 değişkenle Kocaeli, İstanbul, Sakarya ve Tekirdağ Büyükşehir Belediyeleri gizlilik/güvenlik özelliklerini sağlama düzeyleri en düşük olan belediyeler olarak tespit edilmiştir.

Analiz kapsamında belediyelerin web sitelerinde yüksek/düşük düzeyde yer verdikleri ve hiç yer vermedikleri gizlilik/güvenlik değişkenleri de incelenmiştir. Bu bağlamda; Marmara Bölgesi Büyükşehir Belediyeleri'nin web sitelerinde en fazla yer verdikleri değişkenlerin web sayfası ve/veya e-belediyecilik sayfasında kullanıcı adı ve şifre ile profil oluşturulabilmesi ve bu profil kurtarılabilmesi olduğuna yönelik veriler elde edilmiştir. Marmara Bölgesi Büyükşehir Belediyeleri'nin web sayfalarında inceleme döneminde en düşük sayıda tespit edilen değişkenlerin ise; gizlilik/güvenlik politikası ile ilgili bilgilerin mevcudiyeti, bu politikaları onaylama butonunun varlığı, dijital imza ile işlem yapabilme imkanı olduğu sonucuna ulaşılmıştır. Marmara Büyükşehir Belediyeleri'nin web sayfalarında/e-belediyecilik sayfalarında hiç yer vermedikleri değişkenin ise; Web sayfası ve/veya e-belediyecilik sayfasında kişisel verilerin paylaşımına yönelik bilgilendirme süreci olduğu tespit edilmiştir. 3D güvenlik özelliği ise, incelenen belediyelerin web sitesinde ve/veya e-belediyecilik sayfasında açıkça belirtilmediği ve sayfaya girişlerinde vergi mükellefi olarak şifre almak gerektiği için bu değişken ölçümlenememiş, dolayısıyla belirsiz olarak değerlendirilmiştir.

$\mathrm{Bu}$ bağlamda araştırma sonucunda, Marmara Bölgesi Büyükşehir Belediyeleri’nin web sayfalarının/ebelediyecilik uygulamalarının taşıdıkları gizlilik/güvenlik özelliklerinin farklılık gösterdiği; ancak bu farklılık düzeyinin çok yüksek olmadığı değerlendirmesinde bulunulabilir. Dolayısıyla, Marmara Bölgesi Büyükşehir Belediyeleri'nin tamamının web sitesi ve/veya e-belediyecilik sayfalarında kullanıcı adı /şifre ile profil oluşturma ve güvenlik doğrulama sistemi ile hesap kurtarma gibi standart düzeyde gizlilik/güvenlik özelliklerinin bulunduğu tespit edilmiştir. Ancak kişisel verilerin paylaşımı ve belediyelerin gizlilik/güvenlik politikalarına yönelik yurttaşlara yönelik bilgilendirmesinin eksikliği gibi temel problemler incelenen belediyelerin web sitelerinin gizlilik/güvenlik özelliklerinin yeterli düzeyde olmadığı biçiminde değerlendirilebilir. Çünkü, yurttaşların temel bir vatandaşlık hakkı olan bilgi edinme ve kişisel verilerinin korunması alanlarında yetersiz bir erişime sahip olmaları, işlem güvenliği/gizliliği açısından e-yönetişim pratiklerinin hayata geçirilmesi açısından bir eksiklik oluşturmaktadır. 
Tablo 5. Kocaeli İl ve İlçe Belediyelerinin Web Sitelerinin/E-Belediyecilik Sayfalarının Yurttaş ve Sosyal Etkileşim Özelliklerine Yönelik Analiz

\begin{tabular}{|c|c|c|c|c|c|c|c|c|}
\hline $\begin{array}{l}\mathbf{N} \\
\mathbf{0}\end{array}$ & Kategori & فी & 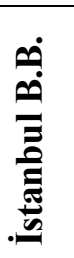 & $\stackrel{0}{0}$ & فी & 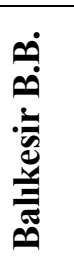 & 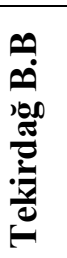 & $\sum_{\substack{1 \\
0}}^{\sum_{0}}$ \\
\hline 1 & $\begin{array}{l}\text { Web sayfası ve/veya e-belediyecilik } \\
\text { sayfası tüm seçilen belediye } \\
\text { temsilcilerine e-posta ile erişime } \\
\text { uygun bir yapıdadır. }\end{array}$ & + & + & + & + & + & + & 6 \\
\hline 2 & $\begin{array}{l}\text { Web sayfası ve/veya e-belediyecilik } \\
\text { sayfası çevrimiçi danışmaya uygun } \\
\text { bir yapıdadır. }\end{array}$ & + & + & + & + & + & \pm & 5 \\
\hline 3 & $\begin{array}{l}\text { Web sayfası ve/veya e-belediyecilik } \\
\text { sayfası kent gündemi ile ilgili } \\
\text { herhangi bir konuda çevrimiçi } \\
\text { oylamaya izin veren bir yapıdadır. }\end{array}$ & - & - & - & - & - & - & $\mathbf{0}$ \\
\hline 4 & $\begin{array}{l}\text { Web sayfası ve/veya e-belediyecilik } \\
\text { sayfası üzerinde belediyelerin } \\
\text { sunduğu hizmetlerle ilgili } \\
\text { değerlendirme yapılmasına imkan } \\
\text { sağlayan çevrimiçi anketler yer } \\
\text { almaktadır. }\end{array}$ & \pm & + & + & + & + & + & 5 \\
\hline & TOPLAM & 2 & 3 & 3 & 3 & 3 & 2 & \\
\hline
\end{tabular}

Belediyelerin web sitelerinde ve/veya e-belediyecilik sayfalarında yurttaş ve sosyal/etkileşim özellikleri seçilen tüm belediye temsilcilerine e-posta ile erişim, web sayfasının çevrimiçi danışmaya uygunluğu, kent gündemi ile ilgili çevrimiçi oylamaların varlığı ve dijital hizmet değerlendirme anketlerinin mevcudiyeti olmak üzere 4 değişken üzerinden analiz edilmiştir.

Tablo-5'e göre, Marmara Büyükşehir Belediyeleri arasında İstanbul, Bursa, Sakarya ve Balıkesir Büyükşehir Belediyeleri 3 değişkenle yurttaş ve sosyal etkileşim özelliklerini en fazla sağlayan belediyeler olarak tespit edilmiştir. Bu belediyeleri ise 2 değişkenle Kocaeli Büyükş̧ehir ve Tekirdağ Büyükşehir Belediyeleri takip etmektedir.

Analiz kapsamında belediyelerin web sitelerinde yüksek/düşük düzeyde yer verdikleri ve hiç yer vermedikleri yurttaş/sosyal etkileşim değişkenleri de incelenmiştir. Bu bağlamda belediyelerin en fazla yer verdikleri özellikler sırasıyla tüm seçilen temsilcilere e-posta ile erişim imkanı; çevrimiçi danışmaya web sayfalarının uygunluğu ve hizmetlerin online olarak değerlendirilmesine imkan tanıyan anketlerin mevcudiyeti olarak tespit edilmiştir. Ayrıca, incelenen belediyelerin web sitelerinde ve/veya ebelediyecilik sayfalarında; "kent gündemi ile ilgili herhangi bir konuda çevrimiçi oylamaya izin vermesi” değişkenine hiç yer vermedikleri sonucuna ulaşılmıştır.

Bu bağlamda araştırma sonucunda, Marmara Bölgesi’nde faaliyet gösteren Büyükşehir Belediyeleri'nin web sayfalarının/e-belediyecilik uygulamalarının taşıdıkları yurttaş ve sosyal etkileşim özelliklerinin farklılık gösterdiği; ancak bu farklılık düzeyinin çok yüksek olmadığı değerlendirmesinde bulunulabilir. Dolayısıyla, incelenen belediyelerin büyük bir bölümünün web sayfalarının çevrimiçi danışmaya uygun bir yapıda olması, seçilen temsilcilerle e-posta ile iletişim kurulabilmesi ve hizmet sunumuna yönelik çevrimiçi anketlerin varlığı gibi değişkenler açısından orta düzeyde yurttaşlarla etkileşim kurabilecek bir 
yapıda oldukları değerlendirmesi yapılabilir. Ancak; özellikle belediyelerin e-yönetişim pratiklerinin de gereği olarak katılımcı demokrasi anlayışı çerçevesinde, web sitelerinde ve/veya e-belediyecilik uygulamalarında yurttaşın katılımını sağlayacak/yurttaşla etkileşim yaratacak "kent gündemi ile ilgili herhangi konuda çevrimiçi oylama" değişkenine hiç yer vermemesi; belediyelerin yurttaş ve sosyal etkileşim düzeyleri açısından önemli bir eksiklik olarak yorumlanabilir.

Tablo 6. Marmara İl ve İlçe Belediyelerinin E-Belediyecilik Hizmetlerinin Yurttaşların Dijital Beceri Düzeylerine Uygunluğunun Analizi

\begin{tabular}{|c|c|c|c|c|c|c|c|c|c|}
\hline No & $\begin{array}{l}\text { Dijital } \\
\text { Beceri } \\
\text { Kategorileri }\end{array}$ & Kategori & فُ & فํ. & فه & 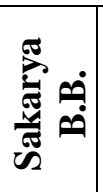 & 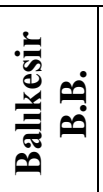 & فी & 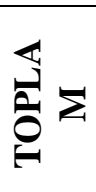 \\
\hline 1 & \multirow[t]{3}{*}{$\begin{array}{l}\text { Operasyonel } \\
\text { Beceriler }\end{array}$} & $\begin{array}{l}\text { E-belediyecilik } \\
\text { hizmetleri sunulan web } \\
\text { sayfasından dosya } \\
\text { indirilip; sayfaya dosya } \\
\text { yüklenebilmektedir. }\end{array}$ & + & + & + & + & + & + & 6 \\
\hline \multirow[t]{2}{*}{2} & & $\begin{array}{l}\text { E-belediyecilik } \\
\text { hizmetleri sunulan web } \\
\text { sayfasında multimedya } \\
\text { içeriği (resim, fotoğraf, } \\
\text { video) indirilip; sayfaya } \\
\text { yüklenebilmektedir. }\end{array}$ & + & + & + & + & + & + & 6 \\
\hline & & TOPLAM & 2 & 2 & 2 & 2 & 2 & 2 & 12 \\
\hline 3 & \multirow{3}{*}{$\begin{array}{l}\text { Formal } \\
\text { Beceriler }\end{array}$} & \begin{tabular}{l}
\multicolumn{3}{l}{ E-belediyecilik } \\
hizmetleri sunulan web \\
sayfasında ilgili konu ile \\
alakalı ek sekme \\
açılabilmektedir.
\end{tabular} & + & + & + & + & + & + & 6 \\
\hline \multirow[t]{2}{*}{4} & & $\begin{array}{l}\text { E-belediyecilik } \\
\text { hizmetleri sunulan web } \\
\text { sayfasının işlem } \\
\text { yapmaya olanak tanıyan } \\
\text { basit ve anlaş1ır bir } \\
\text { yapısı bulunmaktadır. }\end{array}$ & + & - & + & - & - & \pm & 2 \\
\hline & & TOPLAM & 2 & $\mathbf{1}$ & 2 & $\mathbf{1}$ & $\mathbf{1}$ & 1 & 8 \\
\hline 5 & & $\begin{array}{l}\text { E-belediyecilik } \\
\text { hizmetleri sunulan web } \\
\text { sayfasında istenilen bilgi } \\
\text { site içi aramadan } \\
\text { bulunabilmektedir. }\end{array}$ & + & + & + & \pm & \pm & \pm & 3 \\
\hline 6 & $\begin{array}{l}\text { Enformasyonel } \\
\text { Beceriler }\end{array}$ & $\begin{array}{l}\text { E-belediyecilik } \\
\text { hizmetleri sunulan web } \\
\text { sayfasında konu } \\
\text { başlikları rahatlıkla } \\
\text { bulunabilmekte ve } \\
\text { istenen bilgiye ulaşmay1 } \\
\text { kolaylaştıracak anahtar } \\
\text { kelimeleri içermektedir. }\end{array}$ & + & + & + & + & \pm & \pm & 4 \\
\hline
\end{tabular}




\begin{tabular}{|c|c|c|c|c|c|c|c|c|c|}
\hline & & TOPLAM & 2 & 2 & 2 & 1 & 0 & 0 & 7 \\
\hline 7 & \multirow{3}{*}{$\begin{array}{l}\text { Stratejik } \\
\text { Beceriler }\end{array}$} & \begin{tabular}{l}
\multicolumn{3}{l}{ E-belediyecilik } \\
hizmetleri sunulan web \\
sayfası düzenli olarak \\
güncellenmekte olup; \\
bilgi akışını takip \\
etmeye uygun bir \\
yapıdadır.
\end{tabular} & + & + & + & + & + & + & 6 \\
\hline \multirow[t]{2}{*}{8} & & $\begin{array}{l}\text { E-belediyecilik } \\
\text { hizmetleri sunulan web } \\
\text { sayfası "sıça sorulan } \\
\text { sorular" gibi bir bölüme } \\
\text { sahip olup; yurttaşın } \\
\text { yaşadığ1 sorunlara } \\
\text { yönelik çözüm önerileri } \\
\text { içeren bir yapıdadır. }\end{array}$ & + & + & + & - & - & + & 3 \\
\hline & & TOPLAM & 2 & 2 & 2 & 1 & 1 & 2 & 9 \\
\hline \multicolumn{3}{|c|}{ GENEL TOPLAM } & 8 & 7 & 8 & 5 & 4 & 5 & - \\
\hline
\end{tabular}

Belediyelerin e-belediyecilik hizmetleri kapsamında sağladığı hizmetlerin yurttaşların dijital becerileri düzeyleri ile ilintisini ortaya koyma amacı taşıyan değişkenler; operasyonel, formel, enformasyonel ve stratejik olmak üzere 4 temel kategori çerçevesinde analiz edilmiştir. Operasyonel becerilerle bağlantılı olarak belediyenin web sayfasına yurttaş tarafindan dosya/multimedya içeriği indilirip/yüklenebilmesi; formel becerilerle bağlantılı olarak belediyenin web sayfasında ilgili konu ile alakalı ek sekme açılabilmesi ve web sayfasının işlem yapmaya olanak tanıyan basit ve anlaşılır bir yapısı bulunması; enformasyonel becerilerle bağlantılı olarak istenen bilgilerin site içi aramadan bulunabilmesi ve web sayfasında konu başlıkları rahatlıkla bulunabilmesi/ istenilen bilgiye ulaşmayı kolaylaştıracak anahtar kelimelerin varlı̆ğ; stratejik becerilerle bağlantılı olarak e-belediyecilik hizmetleri sunulan web sayfasının güncellenmesi/ bilgi akışını takip etmeye uygun bir yapıda olması ile sıkça sorulan sorular bölümünün varlığı gibi değişkenler incelenmiştir.

Tablo-6’ya göre, Marmara Büyükşehir Belediyeleri arasında Kocaeli ve Bursa Büyükşehir Belediyeleri dijital beceriler ile bağlantılı tüm değişkenleri karşılayan iki belediye olarak tespit edilmiştir. $\mathrm{Bu}$ belediyeleri 7 değişkenle İstanbul Büyükşehir Belediyesi takip etmekte olup; ardından 5 değişkenle Sakarya ve Tekirdağ Büyükşehir Belediyeleri gelmektedir. Dijital becerilerle ilgili olarak en az değişkene sayfasında yer veren belediyenin ise Balıkesir Büyükşehir Belediyesi olduğu sonucuna ulaşılmıştır.

Dijital beceri alt kategorileri açısından ise araştırma sonuçları analiz edildiğinde tüm belediyelerin web/e-belediyecilik sayfalarında dosya/multimedya dosyası indirilip yüklenebildiği sonucuna ulaşılmıştır. Bu bağlamda, incelenen Marmara Bölgesi Büyükşehir Belediyeleri'nin tamamının web/ebelediyecilik sayfalarının yurttaşların operasyonel dijital becerileri ile sayfayı kullanmasına imkan tanıyan bir yapıda olduğu değerlendirmesinde bulunulabilir. Formel beceriler açısından ise; incelenen belediyelerinin tümünün web/e-belediyecilik sayfalarında konuyla ilgili ek seçme açılabildiği; ancak sadece iki belediyenin (Kocaeli ve Bursa Büyükşehir Belediyeleri) web sayfalarının basit ve anlaşılır bir yapıda olduğu sonucuna ulaşılmıştır. Bu bağlamda, incelenen Marmara Bölgesi Büyükşehir Belediyeleri'nin genelinin web/e-belediyecilik sayfalarının orta düzeyde yurttaşların formel dijital becerileri ile sayfayı kullanmasına imkan tanıyan bir yapıda olduğu değerlendirmesinde bulunulabilir. Enformasyonel beceriler açısından ise; incelenen belediyelerin üçünün (Kocaeli, İstanbul ve Bursa Büyükşehir Belediyeleri) web/e-belediyecilik sayfalarında aranan bilginin site içi aramadan bulunabildiği ve dördünde (Kocaeli, İstanbul, Bursa ve Sakarya Büyükşehir Belediyeleri) konu başlıklarının rahatça bulunabildiği/anahtar kelimelerin aramaları kolaylaştırdığı sonucuna ulaşılmıştır. 
Bu bağlamda, incelenen Marmara Bölgesi Büyükşehir Belediyeleri'nin genelinin web/e-belediyecilik sayfalarının orta düzeyde yurttaşların formel dijital becerileri ile sayfayı kullanmasına imkan tanıyan bir yapıda olduğu değerlendirmesinde bulunulabilir. Stratejik beceriler açısından ise; incelenen belediyelerin tamamının web sayfalarının düzenli güncelliği/bilgi akışını takip etmeye uygun bir yapıda olduğu; buna karşın sadece üçünün (Kocaeli, İstanbul ve Bursa Büyükşehir Belediyeleri) yurttaşların karşılaşabileceği problemlerin çözümüne yönelik sıkça sorulan sorular gibi bir bölüme sahip olduğu sonucuna ulaşılmıştır. Bu bağlamda, incelenen Marmara Bölgesi Büyükş̧ehir Belediyeleri'nin genelinin web/e-belediyecilik sayfalarının orta düzeyde yurttaşların stratejik dijital becerileri ile sayfayı kullanmasına imkan tanıyan bir yapıda olduğu değerlendirmesinde bulunulabilir.

Bu bağlamda araştırma sonucunda, Marmara Bölgesi'nde faaliyet gösteren Büyükşehir Belediyeleri'nin web sayfalarının/e-belediyecilik sayfalarının dijital beceri bağlamında yurttaş kullanımına uygunluk açısından orta düzeyde farklılık gösterdiği değerlendirmesinde bulunulabilir. Genel olarak, incelenen belediyelerin web/e-belediyecilik sayfaları dosya/multimedya içeriği indirme/yükleme gibi operasyonel özelliklere; bilgi güncelleme/takip kolaylı̆̆ gibi stratejik özelliklere, ek seçme açılabilmesi gibi formal özelliklere sahip olmakla birlikte; sayfa yapılarının basit ve anlaşılır olmaması, site içi aramada bilgiye erişim güçlüğü, konu başlıkları ve anahtar kelimelerin doğru yerleşimi, sıkça sorulan sorular gibi yurttaşların sorunlarını çözecek bölümlerin varlığı gibi değişkenler formal, enformasyonel ve stratejik özellikleri tam olarak karşılamamaktadır. Bu sonuçlar, belediyelerin hedef kitlelerini oluşturan yurttaşların gerekli dijital becerilere sahip olduğu durumlarda bile e-yönetişim paradigmaları bağlamında e-belediyecilik hizmetlerini etkin bir biçimde kullanmasını negatif yönlü etkileyebilecek önemli bir eksiklik olarak değerlendirilebilir.

\section{GENEL DEĞERLENDİRME VE SONUÇ}

Araştırma, Marmara Bölgesi Büyükşehir Belediyeleri'nin web sayfalarını e-belediyecilik yönüyle analiz etme amacı taşımaktadır. $\mathrm{Bu}$ nedenle, araştırmanın "Belediyelerin web sitelerinde sundukları hizmetlerin, "içerik", "kullanılabilirlik", "servisler/hizmetler", "gizlilik/güvenlik", "yurttaş ve sosyal etkileşim" değişkenleri açısından benzerlik ve farklılıkları nelerdir? " ş̧eklinde geliştirilen sorusu, her değişken için ayrı ayrı cevaplanmıştır.

Araştırma sorusu, içerik kategorisi için; Sakarya Büyükşehir Belediyesi'nin 27 değişkenin 26'sını; Bursa, Balıkesir ve Tekirdağ Büyükşehir Belediyeleri'nin 25'ini, Kocaeli Büyükşehir Belediyesini 24'ünü, İstanbul Büyükşehir Belediyesi'nin 22'sini karşıladığı biçiminde cevaplanmıştır. Bu bağlamda, web siteleri içeriksel bilgi açısından farklılıklar göstermekle birlikte, genel olarak yurttaşların hizmetlerle ilgili bilgi edinmelerini sağlayacak nitelikte içeriksel bilgiye sahip oldukları görülmektedir. Ancak, İstanbul Büyükşehir Belediyesi'nin belediyenin stratejik raporları ve hedeflerine yer verilmemesi gibi kurumsal kimliğin yurttaşlara yansıtılmasını ve bilginin erişiminde şeffaflığın sağlanmasını engelleyebilecek eksiklikleri bulunmaktadır. Ayrıca, dört belediyenin canlı yayın uygulamasına yer vermemesi; bilgi ve iletişim teknolojilerine adaptasyon eksiklikleri olduğunu sonucunu ortaya koymaktadır. Ayrıca, idari görüşmelerin canlı yayınlanmaması, belediye-yurttaş etkileşimi açısından da olumsuz bir durum ortaya koyarak; yurttaşları karar alma süreçlerinin dışında tutmaktadır.

Araştırma sorusu, kullanılabilirlik kategorisi için; Kocaeli ve Bursa Büyükşehir Belediyeleri'nin 22 değişkeninin 21'ini, İstanbul Büyükşehir Belediyesi'nin 19'unu, Tekirdağ Büyükşehir Belediyesi'nin 18'ini, Sakarya Büyükşehir Belediyesi'nin 17'sini, Balıkesir Büyükşsehir Belediyesi'nin ise 15'ini karşıladığı biçiminde cevaplanmıştır. Bu bağlamda, ilgili web sitelerinin kurumsal renklerin kullanımı, Türkçe karakter kullanımına uygun olma, erişim kolaylı̆ğ, sayfanın kısa zamanda ve hızlı yüklenebilmesi, üç tık kuralı ile bilgiye kolay erişim, sitede görsel kargaşa bulunmaması, sayfanın çıktı almaya uygun bir yapıda olması, mobil cihazlarla uyum, çevrimiçi formların bulunması ve bilgilerin düzenli olarak güncellenmesi gibi temel kullanılabilirlik özelliklerini karşıladığı görülmektedir. Ancak, Balıkesir Büyükşsehir Belediyesi'nin yurttaşların hizmetlere çevrimiçi erişim kapasitelerini düşürebilecek çevrimiçi doldurabilecek formların ve aramayı kolaylaştırabilecek çevrimiçi formların bulunmaması gibi bir takım temel eksiklikleri olduğu tespit edilmiştir. Ayrıca, e-yönetişim pratikleri bağlamında tüm paydaş gruplarla etkileşim içerisinde olması gereken belediyelerin en temel eksikliklerinden biri web sitelerinin engelli girişine uyumlu olmamasıdır. 
Araştırma sorusu, hizmet kategorisi için; Balıkesir Büyükşehir Belediyesinin 25 değişkeninin 24'ünü, İstanbul ve Sakarya Büyükşehir Belediyeleri'nin 20'sini, Bursa Büyükşehir Belediyesi'nin 19'unu, Sakarya Büyükşehir Belediyesi'nin 17'sini, Tekirdağ Büyükşehir Belediyesi'nin ise 14'ünü ve Kocaeli Büyükşehir Belediyesi'nin 13'ünü karşıladığı biçiminde cevaplanmıştır. Bu bağlamda, çevrimiç̧i hizmet sunumu açısından bakıldığında Marmara Bölgesi Büyükşehir Belediyelerinin ulaşım, konut, imaristimlak, kent bilgi sistemleri gibi alanlara yoğunlaşmış oldukları; çevrimiçi borç sorgulama/dilek, istek, talep, şikayet formu doldurma, ödeme, işlem takibi gibi alanlara orta düzeyde önem verdikleri, ancak yurttaşların beklentileri arasında olabilecek mesleki bilgi ve beceri kazanımı, istihdam, ruhsat ve izin alma süreçlerinin yönetimi gibi alanlarda dijital hizmet sunumunun yeterli düzeyde olmadığ1 görülmüştür. Sayısal olarak en düşük düzeyde dijital hizmet sunumuna sahip olan ikinci belediye olan Tekirdağ Büyükşshir Belediyesi'nin çevrimiçi borç sorgulama, işlem takip ve ödeme hizmeti sağlamaması; e-belediyecilik sistemi ile elde edilebilecek zaman/maliyet tasarrufu ve yurttaşların hizmet sunumuna kolay erişimi açısından önemli bir eksikliktir. Kocaeli Büyükşehir Belediyesi'nin ise; spor, nikah, arama kurtarma gibi farklı alanlarda dijital hizmet sunumunu incelenen diğer belediyelere göre çeşitlendirmemesi, yurttaşların kurumdan beklentilerinin dijital olarak karşılanması açısından problem yaratmaktadır.

Araştırma sorusu, gizlilik/güvenlik kategorisi için; Bursa Büyükşehir Belediyesi'nin 8 değişkenin 4'ünü, Balıkesir Büyükşehir Belediyesi'nin 3'ünü, diğer 4 belediyenin ise sadece 2'sini karşıladığı biçiminde cevaplanmıştır. Tüm belediyede yer alan gizlilik/güvenlik değişkenleri, kullanıcı adı ve şifre ile profil oluşturup işlem yapabilme ve hesabı e-posta yardımı ile kurtarabilme olarak tespit edilmiştir. Ancak, kişisel verilerin paylaşımı ve gizlilik/güvenlik politikalarıyla ilgili yurttaşlara yönelik bilgilendirmede eksiklik söz konusudur. İşlem güvenliği ve gizliliğinin yetersiz olması ise; e-yönetişim pratiklerinin hayata geçirilmesinin önündeki temel engellerden biridir.

Araştırma sorusu, yurttaş ve sosyal etkileşim kategorisi için İstanbul, Bursa, Sakarya ve Balıkesir Büyükşehir Belediyeleri'nin 4 kriterden 3'ünü; Tekirdağ ve Kocaeli Büyükşehir Belediyeleri'nin ise 2'sini karşıladığ 1 biçiminde cevaplanmıştır. Tüm belediyelerin sitelerinde, kentle ilgili alınacak kararlarda yurttaşların çevrimiçi oylamaya katılmasına izin veren bir dijital uygulamanın bulunmaması, vatandaşları karar alma mekanizmalarının dışına taşımaktadır. Ayrıca, anketler ve e-posta ile seçilmiş temsilcilere erişim imkanı gibi özellikler iletişimin doğrudan etkileşimli değil, dolaylı olarak gerçekleşmesine neden olmaktadır. Bu özellikleri ile incelenen siteler çevrimiçi danışmaya uygun bir yapıda olmakla birlikte; belediye ve yurttaş arasında özellikle karar alma süreçlerine katılım açısından oluşan iletişim engelleri; yeni iletişim teknolojilerinin yerel yönetimlere sağladığ 1 sosyal etkileşim imkanlarından yeterli düzeyde yararlanılmadığını ortaya koymaktadır.

Ayrıca, incelenen 6 Büyükşehir belediyesi web sitesinin tamamı operasyonel dijital becerileri olan yurttaşların sayfayı kullanmalarına imkan tanıyan bir yapıda iken, formal, enformasyonel ve stratejik dijital beceri özelliklerini tam olarak karşılamamaktadırlar. Bu bağlamda, Marmara Büyükşehir Belediyeleri’nin web siteleri aracılığı ile sağladığı hizmetlerin e-yönetişim paradigması dahilinde hizmet sunumu modeli ile uyum göstermekle birlikte, kamu hizmetlerinin etkin ve etkili sunumu açısından bir takım aksaklıkların söz konusu olduğu sonucuna ulaşılşmaktadır.

Türkiye ekonomisinin merkezi olarak görülen Marmara bölgesindeki büyükşehir belediyeleri; bölgedeki kentlerin yüksek oranda göç almasıyla büyüyen nüfusları, kentsel sorunları ve iş yükleri nedeniyle hizmet sunumlarında teknoloji eksenli uygulamalardan azami düzeyde fayda sağlaması beklenen belediyelerdir. E-belediyecilik hizmetleri belediyelerin kent yönetim süreçlerinde ve paydaşlarıyla olan etkileşimlerinde önemli ölçüde kolaylık sağlamakta ve iş yüklerini hafifletmektedir. Söz konusu hizmetler dijital çağın ve çağdaş belediyecilik yaklaşımının da bir gerekliliği olarak yaygınlaşmıştır. Türkiye'nin e-dönüşüm sürecinin bir parçasını oluşturan e-belediye yaklaşımı yerel yönetimlerin daha etkin ve verimli olabilmesine olanak sağlamakta, geleneksel hantal işleyişi sona erdirmektedir. Zaman ve mekandan bağımsız olarak yurttaşların istek ve ihtiyaçlarından anlık haberdar olmayı ve beklentilerine cevap vermeyi sağlayan yeni medya ortamları, e-belediye uygulamaları ile yurttaşların anket gibi yollarla kente yönelik kararlara katılımını da sağlamakta, dijital becerilerinin artmasına katkı sunmaktadır. 
$\mathrm{Bu}$ araştırma Türkiye'de 31 Mart 2019 tarihinde gerçekleştirilen yerel ve mahalli idare genel seçimlerinden yaklaşık 1 yıl öncesinde yapılmış olup aynı araştırmanın söz konusu seçim sonrası yeni belediye yönetimlerinin döneminde tekrarlanması önerilmektedir. Böylece e-belediyecilik uygulamaları ile ilgili güncel pratikleri izlemek, belediyelere o doğrultuda öneriler getirmek mümkün olacaktır. Ebelediye hizmet ve uygulamaları bilgi toplumu sürecinin bir parçası olarak belediyelerin kendilerini sürekli geliştirmesi ve güncellemesini gerektiren uygulamalardır. Ayrıca, ilgili belediyelerin, e-yönetişim paradigması doğrultusunda "hizmet-sunum modeli" çerçevesinde web sitelerinde içerik, kullanılabilirlik, hizmet, gizlilik/güvenlik/ yurttaş ve sosyal etkileşim çerçevesinde temel eksikliklerini belirleyerek kamu hizmetlerinin etkileşimli aktarımını güçlendirmeleri gerekmektedir. Bu önerilere ek olarak, yurttaşların karar alma süreçlerine daha aktif katılımı ile e-yönetişim sürecinde devlet-vatandaş işbirliği modeline yönelik uygulamalarla belediye hizmetlerinin gelişimi etkileşimli bir yönetişim sürecine entegrasyon açısından atılması gereken adımlar arasında yer almaktadır.

Bilgilendirme/Acknowledgement: Bu araștırma, "E-Yönetişim Bağlamında Yeni Medya Ortamlarında BelediyeVatandaş Etkileşimi: Kocaeli ili Örneği” başlıklı 1717K012 sayılı TÜBỉTAK SOBAG 1001 destekli araştırma projesinin verileri ve ölçeği kullanılarak hazırlanmıştır. Bu çalışma, 4. International Scientific Research Congress (IBAD-2019)'da, sözlü bildiri olarak sunulmuştur.

\section{KAYNAKÇA}

Arduini, D. vd. (2013). The role of technology, organization and contextual factors in the development of e-government services: An empirical analysis on İtalian local public administrations. Structural Change and Economic Dynamics, 27, 177-189.

Berelson, B. (1952). Content analysis in communication research. Glencoe, III: Free Press.

Büyüköztürk, Şener vd. (2018). Bilimsel araştırma yöntemleri. Ankara: Pegem Yayınevi.

Çarıkçı, O. (2010). Türkiyede e-devlet uygulamaları üzerine bir araştırma. Süleyman Demirel Üniversitesi Sosyal Bilimler Enstitüsü Dergisi, 2(12), 95-122.

Dawes, S.S. (2008). The evolution and continuing challenges of e-governance. Public Administration Review, $68 \quad(1), \quad 86-102 . \quad 1 \quad$ Ocak 2019 tarihinde https://www.researchgate.net/publication/227608705_The_Evolution_and_Continuing_Challe nges_of_E-Governance adresinden erişildi.

Delitheou V. ve Maraki M. (2010). Research into citizens' attitude towards electronic municipal services (e-local government). Journal of Public Administration and Policy Research, 2(3), 39-45.

Demirel, D. (2010). Yönetişimde yeni bir boyut: e-yönetişim, Türk İdare Dergisi, 466, 65-94.

Doğan C. K. ve Ustakara F. (2013). Kamuda bir yapılanma dönüşümü olarak e-devlet ve e-yönetişim ilişkisi üzerine. Küresel İktisat ve Işsletme Çalışmaları Dergisi, 2(3),01-12.

E-Government Development Index (2014). 15 Haziran 2019 tarihinde https://publicadministration.un.org/egovkb/en-us/Reports/UN-E-Government-Survey-2014 adresinden erişildi.

Ersöz, S. (2005.) İnternet ve demokrasinin geleceği. Selçuk İletişim Dergisi, 3(4), 122-129.

Gallego-Álvarez, I. vd. (2010). Are determining factors of municipal e-government common to a worldwide municipal view? An intra-country comparison". Government Information Quarterly, 27, 423-430.

Ganapathy, V.B. ve Kumar. K. (2014). E-government: concepts and applications. IPASJ International Journal of Computer Science (IIJCS). 1 Nisan 2019 tarihinde https://ipasj.org/IIJCS/Volume2Issue8/IIJCS-2014-08-03-9.pdf adresinden erişildi.

Gordon, T.F. (2012). E-governance and its value for public administration. 25 Ocak 2018 tarihinde http://www.tfgordon.de/publications/gordon2004a.pdf adresinden erişildi. 
Göymen, K. (2000). Türkiye'de yerel yönetimler ve yönetişim: gereksinmeler, önermeler, yönelimler. Çağdaş Yerel Yönetimler Dergisi, 9(2), 3-13.

Güler, B. A. (2001). Yerel yönetimler ve internet. HABİTAT II İstanbul. 5 Ülke Raporu, Yönetişim Alt Bölümü, İstanbul.

Henden, H.B. (2005). Katılımcı yerel yönetim anlayışında e-belediyeciliğin yeri ve önemi. Uluslararası Insan Bilimleri Dergisi, 1(1), 1-13.

Henden, H. B ve Henden, R. (2005). Yerel yönetimlerin hizmet sunumlarındaki değişim ve ebelediyecilik. Elektronik Sosyal Bilimler Dergisi, 4(14), 48-66.

Holzer, M. vd. (2015). Digital governance in municipalities worldwide. 10 Mart 2019 tarihinde https://spaa.newark.rutgers.edu/sites/default/files/files/EGov/Publications/Digital\%20Governa nce\%20in\%20Municipalities\%20Worldwide\%20(2015-16).pdf. adresinden erişildi.

Kanungo, S. (2004).On the emancipatory role of rural information systems. Information Technology and People, 17(4), 407-422.

Krippendorff, K. (2004). Content Analysis: An Introduction to Its Methodology. Newbury Park, CA: Sage.

Lethbridge, J. (2015). Digitalisation of local authority services in europe" in "new forms of service delivery for municipalities, the contribution of social dialogue and good practice for well-being at work'. 10 Mart 2019 tarihinde http://www.psiru.org/sites/default/files/2015-12-MDigitalisationlocalauthorityservicesEurope.pdf. adresinden erişildi.

Lofstedt, U. (2005). E-government-assesment of current research and some proposals for future directions. International Journal of Public Information Systems, (1), 39-52.

Mastek. e-Governance solutions, making a valuable difference. 10 Mart 2019 tarihinde www.dmreview.com adresinden erişildi.

Mecek, M. (2017). E-devlet ve e- belediye: kavramsal çerçeve ve türkiye'de belediye web sitelerine yönelik yapılan çalışmaların incelenmesi. Süleyman Demirel Üniversitesi İktisadi ve İdari Bilimler Fakültesi Dergisi, 22(15), 1815-1851.

Mecek, M. (2018). E-belediyecilik, halkla ilişkiler, bilgi edinme, şeffaflık, vb. unsurlar açısından belediye web sayfalarının kullanılması ve etkinlik analizi: Bolvadin belediyesi örneği. Uluslararası Bolvadin Sempozyumu Bildiriler Kitabı, 2307-2350.

Nohutçu, A ve Demirel, D. (2005). E-devlet: genel bir çerçeve ve teorik bir yaklaşım. Türk İdare Dergisi, 35-56.

Ogra, A. ve Thwala, W.D. (2014). E-Government perspectives: evolution, strategies and practices. Proceedings of the International Conference on e-Business, e-Commerce, e-Management, $e$ Learning and e-Governance . 61-66.

Postac1, T. ve Ayhan, A. (2013), E-dönüşümün kent yaşamına etkileri (e-belediye) ve yeni beklentiler. Anahtar Dergisi, 29, 17-19.

Serenli, A. (2013). Türkiye'de yerel yönetimlerin e-devlet uygulamaları kapsamında büyükşehir belediyeleri web sitelerinin işlevselliği. 1-20. 25 Haziran 2019 tarihinde http://www.abdullahserenli.com/img/1 227241762015_9272119402i.pdf adresinden erişildi.

Sobacı M. Z. ve Altık, R. (2011). Türkiye'de büyükşehir belediyelerinin e-katılım uygulamaları: website içerik analizi. VIII.Кати Yönetimi Forumu: Кати Yönetimi ve Teknoloji içinde. Ankara: TODAİE Yayınları, 786-803.

Schröder, K. ve Schmalfeld, U. (2002). E-government in den kommunen - deutschland holt auf, Finanswirtschaft, 56(7). 
Silverman, David (2001). Interpreting Qualitative Data: Methods for Analysing Talk, Text and Interaction. London: Sage.

Stahl, B. C. (2005). The paradigm of e-commerce in e-government and e-democracy. W. Huang, K. Siau ve K. K. Wei (Ed.). Electronic Government Strategies and Implementation içinde. Hershey PA.; Idea Group Publishing.

Strauss, A. ve Corbin, J. (1990). Basics of qualitative research: grounded theory procedures a techniques. Thousand Oaks: Sage Publications.

Şat, N. (2016). Türkiye'de büyükşehir belediyelerinin genel ağ (web) sitelerinin analizi. Türk İdare Dergisi, 482, 183-236.

Tejasvee, S. vd. (2010). E-governance and effective deliverance of information and services to citizens architecture. International Journal of Computer Science and Information Technologies, 1(4), 298-302.

TESEV (2008). İyi yönetişim el kitabı. (Ed. Fikret Toksöz). İstanbul: Tesev Yayınları.

Ulaştırma Denizcilik ve Haberleşme Bakanlığı (2016). 2016-2019 Ulusal e-devlet stratejsi ve eylem plani. 5 Ocak 2019 tarihinde http://www.edevlet.gov.tr/2016-2019-ulusaledevletstratejisiveeylemplanitaslagi.pdf adresinden erişildi.

UNESCO (2002). Country profiles of e-governance. 25 Ocak 2019 tarihinde https://unesdoc.unesco.org/ark:/48223/pf0000127601 adresinden erişildi.

Vandeursen, A. (2014). Measuring digital skills, from digital skills to tangible outcomes project report:measuring digital skills. 21 Şubat 2019 tarihinde http://www.lse.ac.uk/media-and communications/assets/documents/research/projects/disto/Measuring-Digital-Skills.pdf adresinden erişildi.

Waisanen, B. (2002). The future of e-government: technologi-fueled. Public Management, 84(5), 6-9.

Yıldırım, A. ve Şimsek, H. (2018). Sosyal bilimlerde nitel araştırma yöntemleri. Ankara: Seçkin Yayıncilik. 